\title{
Simulation of Water Level, Streamflow, and Mass Transport for the Cooper and Wando Rivers near Charleston, South Carolina, 1992-95
}

BY PAUL A. CONRADS and PAULEY A. SMITH

U.S. GEOLOGICAL SURVEY

Water-Resources Investigations Report 96-4237

Prepared in cooperation with the

SOUTH CAROLINA DEPARTMENT OF HEALTH AND ENVIRONMENTAL CONTROL, OFFICE OF OCEAN AND COASTAL RESOURCE MANAGEMENT, CHARLESTON HARBOR PROJECT

Columbia, South Carolina 1996

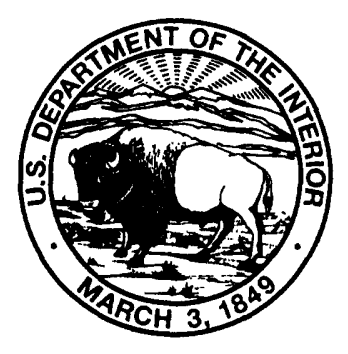




\title{
U.S. DEPARTMENT OF THE INTERIOR BRUCE BABBITT, Secretary
}

\author{
U.S. GEOLOGICAL SURVEY
}

Gordon P. Eaton, Director

The use of firm, trade, and brand names in this report is for identification purposes only and does not constitute endorsement by the U.S. Government.

For additional information write to:

District Chief

U.S. Geological Survey

Stephenson Center-Suite 129

720 Gracern Road

Columbia, SC 29210-7651
Copies of this report can be purchased from:

U.S. Geological Survey

Branch of Information Services

Box 25286

Denver, CO 80225-0286 


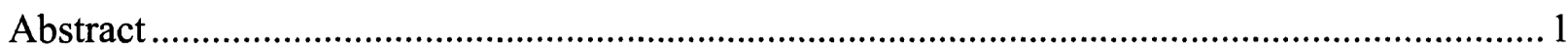

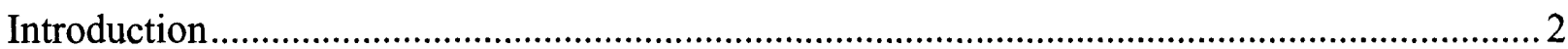

Purpose and scope

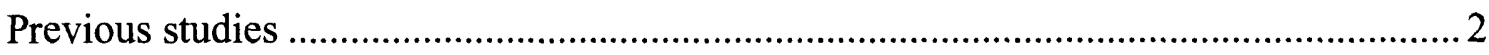

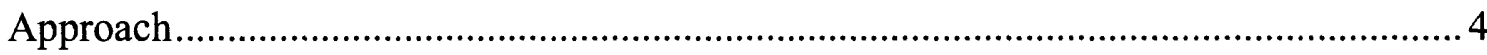

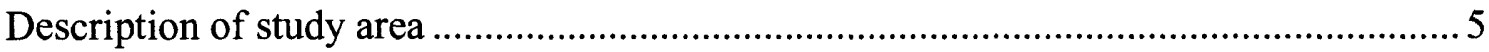

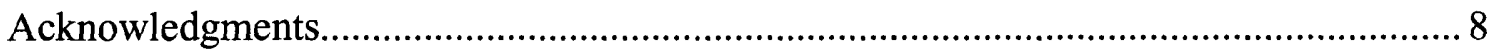

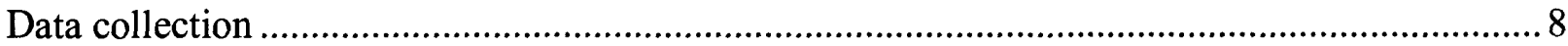

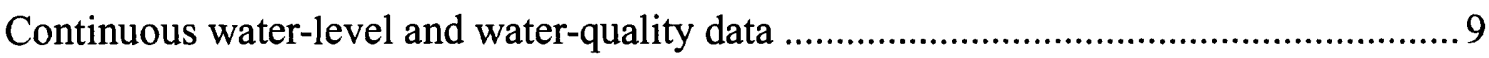

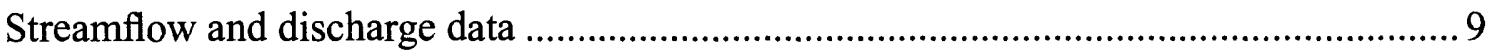

Channel-geometry data ..........................................................................................

Simulation of water level, streamflow, and mass transport .....................................................

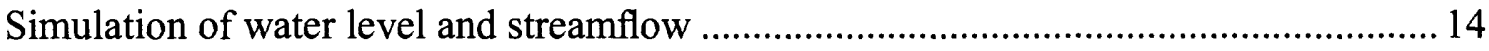

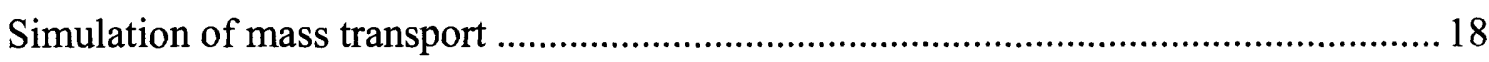

Calibration and validation of water level, streamflow, and mass transport ......................20

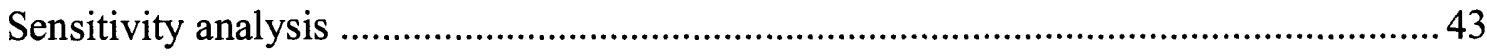

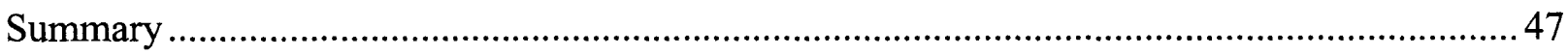

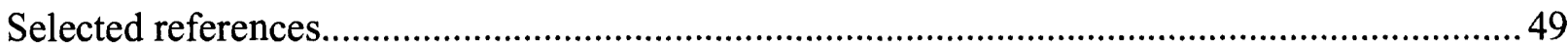

\section{FIGURES}

1-4. Maps showing:

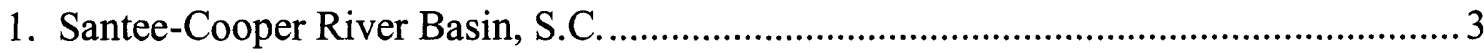

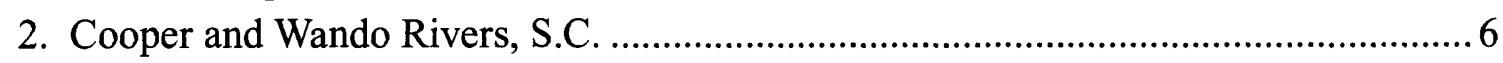

3. Location of continuous-monitoring stations on the Cooper and

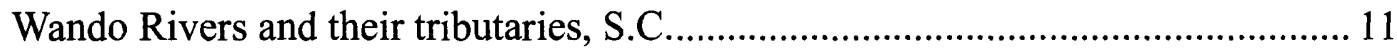

4. Location of streamflow stations on the Cooper and Wando Rivers and their tributaries, S.C.

5-7. Diagrams showing:

5. Idealized BRANCH model schematization .................................................................. 16

6. BRANCH model schematization for the Cooper and Wando Rivers, S.C. ................ 17

7. Branched Lagrangian Transport Model schematization for the Cooper and Wando Rivers, S.C. 


\section{FIGURES--Continued}

8-18. Hydrographs showing:

8. Sensitivity of simulated salinity concentrations to changes in downstream datum adjustment for two locations on the Cooper River, S.C., April 23 to May 8, 1993

9. Sensitivity of simulated water levels and streamflow to changes in downstream datum adjustment for two locations on the Cooper River, S.C., April 23 to May 8, 1993

10. Simulated and measured water levels used in the hydraulic model calibration for four locations on the Cooper River and two locations on the Wando River, S.C., July 30, 1992

11. Simulated streamflow from two models used in the hydraulic model calibration for four locations on the Cooper River, S.C., July 30, 1992 .............. 30

12. Simulated and measured streamflow used in the hydraulic model calibration for five locations on the Wando River, S.C., July 30, 1992 ............... 32

13. Simulated and calculated salinity concentrations used in the transport model calibration for two locations on the Cooper River and two locations on the Wando River, S.C., July 30-31, 1992

14. Simulated and measured water levels used in the hydraulic model validation for three locations on the Cooper River and two locations on the Wando River, S.C., September 24, 1992

15. Simulated streamflow from two models used in the hydraulic model validation for four locations on the Cooper River, S.C., September 13, 1992

16. Simulated and measured streamflow used in the hydraulic model validation for five locations on the Wando River, S.C., September 24, 1992

17. Simulated and calculated salinity concentrations used in the transport model validation for one location on the Cooper River and two locations on the Wando River, S.C., September 24-25, 1992 40

18. Simulated and measured streamflow for two locations on Goose Creek, S.C., October 3 and December 4, 1992

19. Sensitivity of water levels and streamflow to changes in gage datum, channel geometry, and roughness coefficient for the Cooper River at Army Depot near North Charleston, S.C., July 28-30, 1992

20. Sensitivity of simulated salinity concentrations to changes in gage datum, channel geometry, roughness coefficient, and dispersion factor for the Cooper River at Army Depot near North Charleston, S.C., July 28-30, 1992 46 


\section{TABLES}

1. Continuous water-level and water-quality stations in the vicinity of Charleston Harbor, S.C., and the constituents monitored

2. Streamflow stations in the vicinity of Charleston Harbor, S.C., and measurement dates.

3. Boundary locations, data types, data sources, and data frequency 18

4. Summary of water-level calibration simulations for four locations on the Cooper River and two locations on the Wando River, S.C.

5. Summary of streamflow calibration simulations for four locations on the Cooper River and five locations on the Wando River, S.C.

6. Summary of salinity calibration simulations for two locations on the Cooper River and two locations on the Wando River, S.C. 34

7. Summary of water-level validation simulations for three locations on the Cooper River and two locations on the Wando River, S.C. 36

8. Summary of streamflow validation simulations for four locations on the Cooper River and five locations on the Wando River, S.C. 38

9. Summary of salinity validation simulations for one location on the Cooper River and two locations on the Wando River, S.C 41

10. Summary of streamflow simulations for two locations on Goose Creek, S.C 43 


\section{ABBREVIATIONS AND VERTICAL DATUM}

Abbreviations used in this report:

$\begin{array}{ll}\text { BLTM } & \text { Branched Lagrangian Transport Model } \\ \text { FW } & \text { Freshwater } \\ \text { ppt } & \text { Parts per thousand } \\ \text { SA } & \text { Tidal saltwaters suitable for primary and secondary contact recreation. } \\ & \begin{array}{l}\text { Daily average dissolved-oxygen concentration not less than } 5.0 \mathrm{mg} / \mathrm{L} \\ \text { (milligrams per liter) with a low of } 4.0 \mathrm{mg} / \mathrm{L} .\end{array} \\ \text { SB } & \text { Tidal saltwaters suitable for primary and secondary contact recreation. } \\ & \text { Dissolved-oxygen concentration not less than } 4.0 \mathrm{mg} / \mathrm{L} \text {. } \\ \text { SCDHEC } & \text { South Carolina Department of Health and Environmental Control } \\ \text { SFH } & \text { Shellfish harvesting waters } \\ \text { USACOE } & \text { U.S. Army Corps of Engineers } \\ \text { USEPA } & \text { U.S. Environmental Protection Agency } \\ \text { USGS } & \text { U.S. Geological Survey } \\ \text { WASP4 } & \text { Water Analysis Simulation Program--version } 4.0\end{array}$

Sea level: In this report "sea level" refers to the National Geodetic Vertical Datum of 1929--a geodetic datum derived from a general adjustment of the first-order level nets of the Unites States and Canada, formerly called Sea Level Datum of 1929. 


\title{
SIMULATION OF WATER LEVEL, STREAMFLOW, AND MASS TRANSPORT FOR THE COOPER AND WANDO RIVERS NEAR CHARLESTON, SOUTH CAROLINA, 1992-95
}

\author{
By Paul A. Conrads' and Pauley A. Smith ${ }^{2}$
}

\begin{abstract}
The one-dimensional, unsteady-flow model, BRANCH, and the Branched Lagrangian Transport Model (BLTM) were calibrated and validated for the Cooper and Wando Rivers near Charleston, South Carolina. Data used to calibrate the BRANCH model included water-level data at four locations on the Cooper River and two locations on the Wando River, measured tidal-cycle streamflows at five locations on the Wando River, and simulated tidal-cycle streamflows (using an existing validated BRANCH model of the Cooper River) for four locations on the Cooper River. The BRANCH model was used to generate the necessary hydraulic data used in the BLTM model. The BLTM model was calibrated and validated using time series of salinity concentrations at two locations on the Cooper River and at two locations on the Wando River. Successful calibration and validation of the BRANCH and BLTM models to water levels, streamflows, and salinity were achieved after applying a positive 0.45 foot datum correction to the downstream boundary. The sensitivity of the simulated salinity concentrations to changes in the downstream gage datum, channel geometry, and roughness coefficient in the BRANCH model, and to the dispersion factor in the BLTM model was evaluated. The simulated salinity concentrations were most sensitive to changes in the downstream gage datum. A decrease of 0.5 feet in the downstream gage datum increased the simulated 3-day mean salinity concentration by 107 percent (12.7 to 26.3 parts per thousand). The range of the salinity concentration went from a tidal oscillation with a standard deviation of 3.9 parts per thousand to a nearly constant concentration with a standard deviation of 0.0 parts per thousand. An increase in the downstream gage datum decreased the simulated 3-day mean salinity concentration by 47 percent (12.7 to 6.7 parts per thousand) and decreased the standard deviation from 3.9 to 3.4 parts per thousand.
\end{abstract}

\footnotetext{
1. U.S. Geological Survey

2. South Carolina Department of Health and Environmental Control
} 


\section{INTRODUCTION}

The Cooper and Wando Rivers are tidally affected rivers that are major tributaries to Charleston Harbor, which is located near the middle of the South Carolina coast (fig. 1). The water quality of Charleston Harbor and its tributaries, the Cooper, Wando, and Ashley Rivers is increasingly being stressed by point-source (municipal and industrial wastewater effluent) and non-point source pollutant loadings.

As the Charleston area continues to grow, demands on its water resources increasingly conflict. The Harbor and its tributaries function as an important economic, natural-habitat, and aesthetic resource. Charleston Harbor is the second largest container port on the East Coast, with the shipping traffic passing through the Harbor to terminal ports located on the Cooper and Wando Rivers. The tributary rivers and tidal creeks also are critical fisheries habitats. In addition, recreational use of these coastal waters is essential to the growing tourism and retirement communities of the Charleston area and the South Carolina coast.

In May 1992, the U.S. Geological Survey (USGS), in cooperation with the South Carolina Department of Health and Environmental Control (SCDHEC), Office of Ocean and Coastal Resource Management, Charleston Harbor Project, initiated a study to develop a computer simulation model of the water quality of the Cooper and Wando Rivers. The simulation model of the two-river system will allow water-resource managers and regulators in the State to assess the effects of regulatory decisions on the water quality of the Cooper and Wando Rivers.

\section{Purpose and Scope}

The purpose of this report is to present the results the application of the one-dimensional, unsteady-flow model (BRANCH) and the Branched Lagrangian Transport Model (BLTM) to the Cooper and Wando Rivers. The modeling effort for the Cooper and Wando Rivers was undertaken in two phases. The scope of the first phase was to calibrate and validate the hydraulic and masstransport models for simulating the movement of a conservative constituent (salinity) in the system. These models simulate the water-level, streamflow, and mass transport of the two-river system. The second phase was to calibrate and validate the water-quality model for simulating the fate and transport of non-conservative constituents (nutrients and dissolved oxygen). This report documents the first phase of the modeling effort. The calibration, validation, and application of the BLTM for non-conservative constituents is not discussed in this report.

\section{Previous Studies}

There have been numerous environmental, hydrologic, sedimentation, and modeling studies of Charleston Harbor and the Cooper and Wando Rivers (Chestnut, 1989; Kjerfve, 1976; Patterson, 1983; Teeter, 1989; Teeter and Pankov,1989; Van Dolah and others, 1990). This investigation builds on previous studies by the USGS, the University of South Carolina School of Public Health, and the SCDHEC (Bower and others, 1993; McKellar and others, 1995; South Carolina Department of Health and Environmental Control, 1991). The USGS previously applied the BRANCH model to the Cooper River and Bushy Park Reservoir to determine retention times 


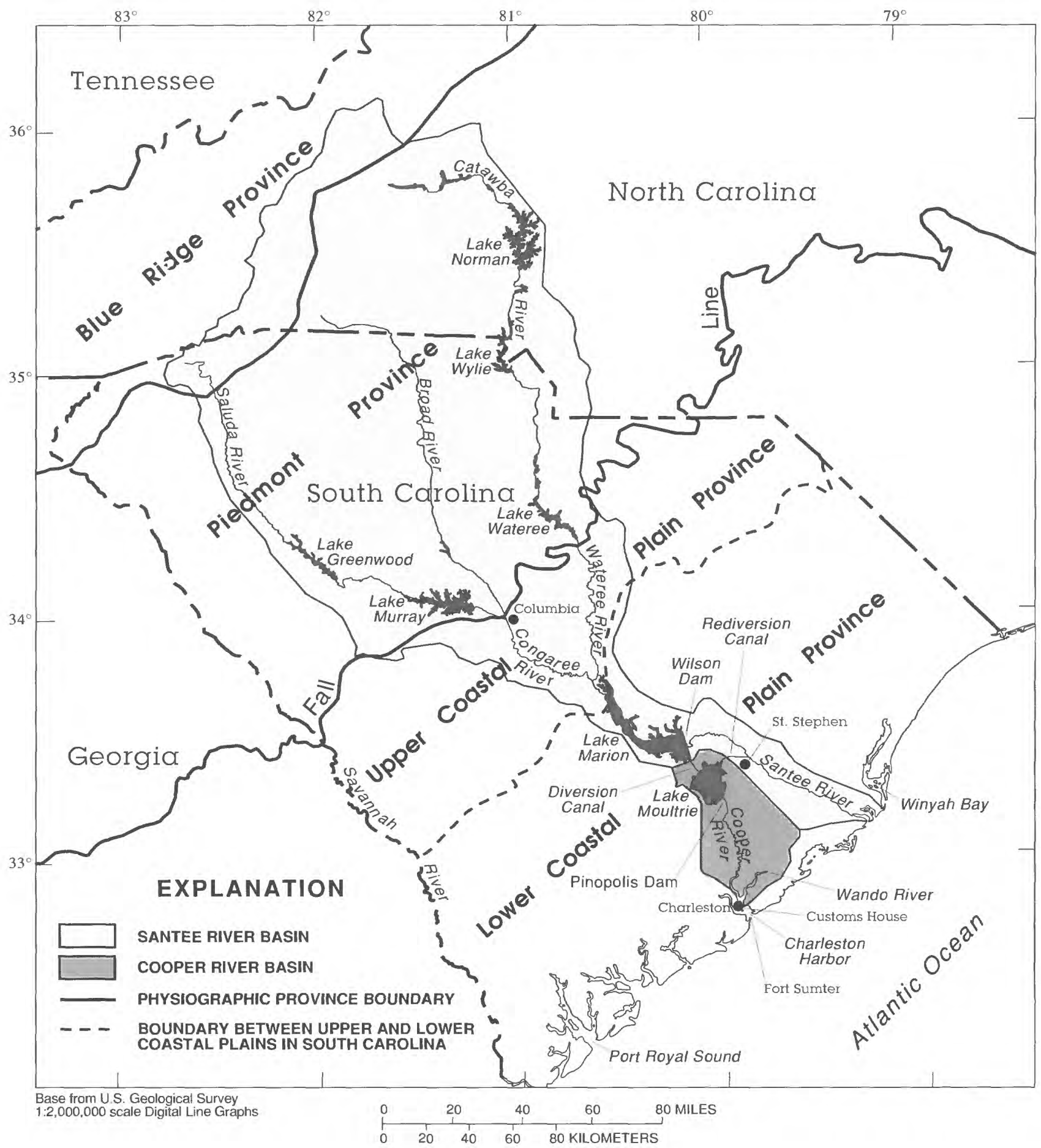

Figure 1. Santee-Cooper River Basin, S.C. 
in the reservoir. McKellar applied the BRANCH model to Goose Creek in a study of nutrient fluxes of tidal marshes (McKellar and others, 1995). The SCDHEC applied a U.S. Environmental Protection Agency (USEPA) water-quality model, the Water Analysis and Simulation Program-4 (WASP4) (Ambrose and others, 1988), to the Cooper and Wando Rivers (South Carolina Department of Health and Environmental Control, 1991). Effluent-discharge limits for the Cooper River are currently (1996) based on results from simulations using WASP4.

\section{Approach}

Dissolved-oxygen concentration is one of the primary water-quality constituents used as an indicator of the health of a waterbody. The ability to simulate the concentration of dissolved oxygen is necessary for water-resource managers to assess the effects of point- and nonpointsource pollution on a waterbody. The models described in this report will principally be used by water-resource managers to determine the assimilative capacity of the Cooper and Wando Rivers. The ability of a stream to assimilate oxygen-demanding substances is a function of streamflow, temperature, velocity, depth, and channel configuration, along with its ability to absorb oxygen from the atmosphere. In terms of water-resource management, this capacity or loading is expressed in terms of pounds per day of ultimate oxygen demand that can be assimilated during a particular set of hydrologic conditions without violating the State water-quality standards for dissolved oxygen.

In discussions with the cooperating agency concerning the study plan to simulate the dissolved-oxygen concentrations in the Cooper and Wando Rivers, it was decided that the model applied to the system would have to be readily available and usable by water-resource managers. A one-dimensional unsteady-flow model and a one-dimensional unsteady transport and waterquality model were applied to the two-river system. The unsteady-flow model, BRANCH. was used to generate the required hydraulic data for input into the BLTM, which was used to simulate the transport of the conservative constituent salinity.

The general approach to applying the models was to calibrate and validate the hydraulic and mass-transport models by first simulating the movement of the conservative constituent. Concentration of a conservative constituent is not affected by biological degradation or chemical reaction, but is changed by increases or decreases of the constituent in the subreach by dilution in response to changing streamflow conditions. Salinity is a conservative constituent and is an effective natural tracer for calibrating and validating mass transport. After successfully calibrating and validating the model for the mass transport of a conservative constituent (salinity), the non-conservative constituents (nutrients and dissolved oxygen) can be simulated.

Several types of data were required for application of the models. A large data-collection effort was completed during 1992-95 (P.A. Conrads, unpub. data). Data that were required to calibrate and validate the hydraulic and transport models included (1) continuous water level or streamflow, and specific conductance at the upstream and downstream boundaries and at selected interior locations, (2) tidal-cycle measurements of streamflow at boundaries and selected interior locations, (3) channel geometry, and (4) local wastewater inflow and withdrawal rates. 
The BRANCH model had been applied to selected reaches within the study area for two previous studies. These existing models were modified and incorporated into the larger model of the two-river system. The calibrated and validated BRANCH model of the Cooper River (Bower and others, 1993) was used for the upper reaches of the Cooper River above Goose Creek (fig. 2). The model was extended to incorporate the lower Cooper and the Wando Rivers with a downstream boundary at the Customs House (fig. 2). A BRANCH model of Goose Creek (McKellar and others, 1995) was incorporated into the model.

The area of major water-quality concern is the lower reach of the Cooper River in the vicinity of Goose Creek. Therefore, emphasis was placed on the accuracy of the calibration and validation process for the area below the confluence of the West and East Branches of the Cooper River and below S.C. Highway 41 on the Wando River. A successfully applied hydraulic and mass-transport models of the two-river system should yield water levels, streamflows, and salinity concentrations that agree closely with field measurements of those parameters. However, there are inherent limitations in the application of one-dimensional models to a highly complex, threedimensional environmental system. Because the end use of the model will be to generate the necessary hydraulic data for a non-conservative constituent fate-and-transport model of the system, emphasis during the calibration and validation process was placed on satisfactory simulations of salinity transport.

\section{Description of Study Area}

The Cooper and Wando Rivers are located in the lower Coastal Plain physiographic province in the lower part of the Santee-Cooper River Basin (fig. 1). This basin covers $21,700 \mathrm{mi}^{2}$ (square miles) and is the second largest drainage basin on the East Coast. Charleston Harbor experiences semi-diurnal tides with mean- and spring-tidal ranges of 5.09 and $5.90 \mathrm{ft}$ (feet), respectively, at the entrance at Fort Sumter (National Oceanic and Atmospheric Administration, 1995). The harbor and its tributary rivers, the Ashley, Cooper, and Wando Rivers, drain $253.3 \mathrm{mi}^{2}$ consisting of 54.6 percent forest, 15.0 percent wetlands, 10.7 percent urbanization, 10.5 percent water, 5.5 percent scrub and scrubland, 3.3 percent agricultural land, and 0.4 percent barren land (South Carolina Department of Health and Environmental Control, 1996).

The Santee and Cooper Rivers have long histories of anthropogenic changes (Kjerfve, 1976). Rice plantations, with large diked fields along the banks of the Cooper and Wando Rivers, flourished in the 18th and 19th centuries. With the advent of mechanized rice harvesting, rice production diminished because heavy machinery was unsuitable for the clayey soils of the area. With the increased demand for electric power in the 1930's, the Santee-Cooper Project created two freshwater lakes by diverting flows from the Santee River and using the naturally high topographic relief adjacent to the Cooper River to generate hydroelectric power. The project was completed in 1941 by construction of Wilson Dam across the Santee River that formed Lake Marion, and by construction of Pinopolis Dam near the headwaters of the West Branch Cooper River that formed Lake Moultrie (figs. 1, 2). A 4-mile diversion canal was built to connect the two lakes. The Jefferies Hydroelectric Plant was built at Pinopolis Dam. The approximate watersurface elevation difference between Lake Moultrie and the Cooper River is $70 \mathrm{ft}$, as compared to an 18-ft difference between the water-surface elevations of Lake Marion and the Santee River (Kjerfve, 1976). 


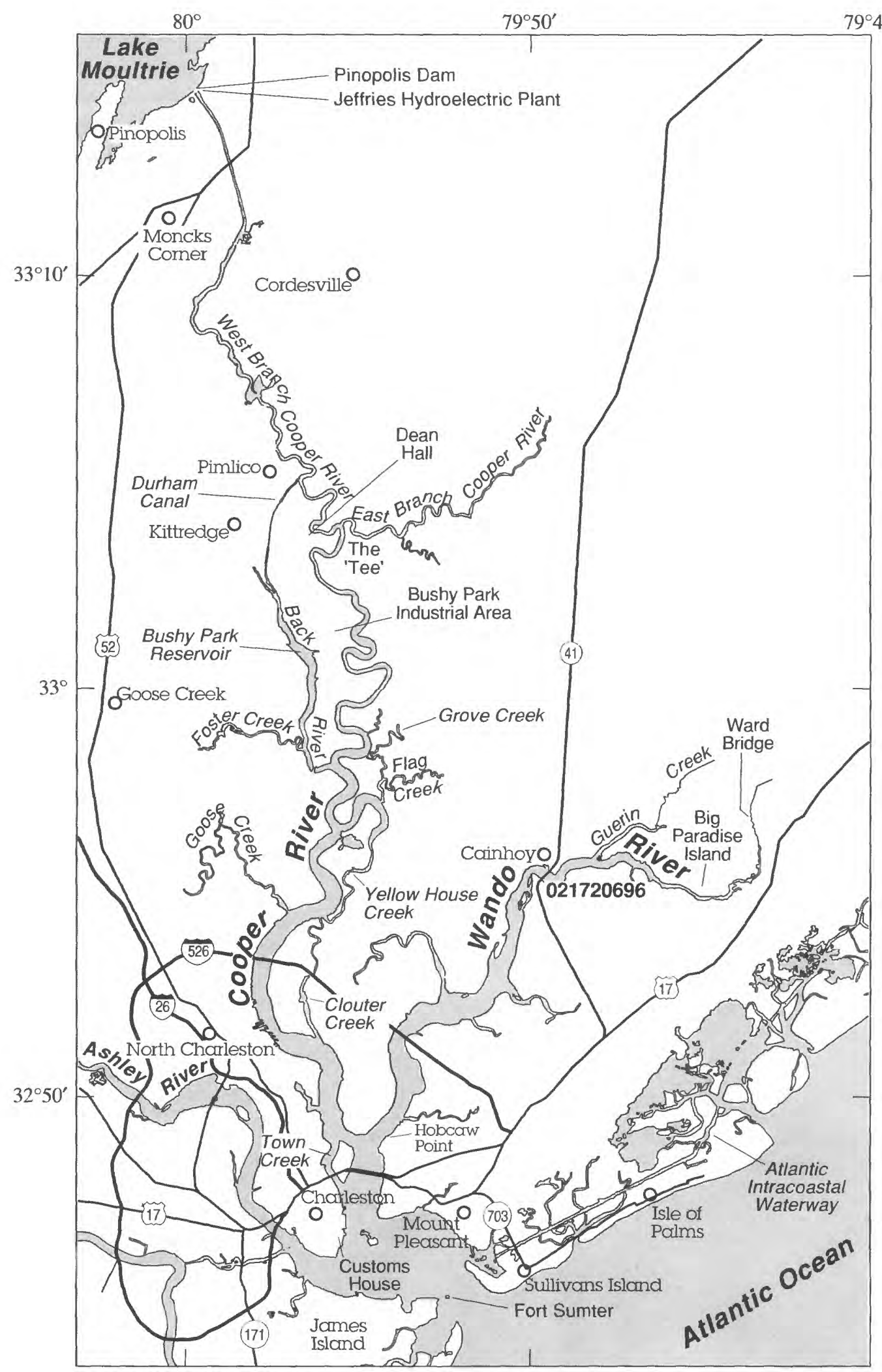

Base from U.S. Geological Survey

$1: 100,000$ scale Digital Line Graphs

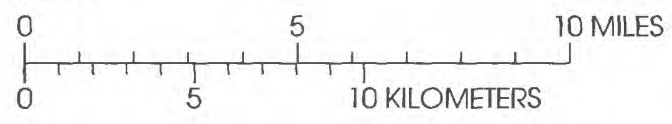

Figure 2. Cooper and Wando Rivers, S.C. 
The diverted flows from the Santee River to the West Branch Cooper River had pronounced effects on the Cooper River and Charleston Harbor (Kjerfve, 1976). The Cooper River was transformed from a tidal slough with a net downstream discharge of $71 \mathrm{ft}^{3} / \mathrm{s}$ (cubic feet per second) to a riverine system with a streamflow of $15,600 \mathrm{ft}^{3} / \mathrm{s}$ (U.S. Army Corps of Engineers, 1966). The diversion of water transformed Charleston Harbor from a well-mixed estuary to a partially mixed estuary and an efficient sediment trap (Patterson, 1983). After diversion, mean salinity values in Charleston Harbor dropped from 31 to $16 \mathrm{ppt}$ (parts per thousand) (Kjerfve and Magill, 1990).

In 1954, the Bushy Park industrial area was established along the east bank of the Back River and the west bank of the Cooper River. To provide water to the industrial users, a freshwater reservoir was constructed by damming the Back River at the lower end near the confluence with the Cooper River. Durham Canal was constructed as a conduit between the upper end of the reservoir and the freshwater part of the Cooper River. (South Carolina Water Resources Commission, 1979).

In 1985, the U.S. Army Corps of Engineers (USACOE) rediverted flows from Lake Moultrie back to the Santee River to alleviate a severe sedimentation problem in Charleston Harbor created by the diversion of freshwater flows. The diversion was accomplished by building an 11-mile rediversion canal from Lake Moultrie to the Santee River. A hydroelectric plant was built at St. Stephen to help offset lost power generation from the Jefferies Hydroelectric Plant (figs. 1, 2). The approximate difference in the water levels between the rediversion canal and St. Stephen tailrace is $46 \mathrm{ft}$. (Kjerfve, 1976). After the rediversion project, the flows to the Cooper River were reduced to a level that would alleviate sedimentation in the harbor while ensuring an adequate freshwater source to the Bushy Park Reservoir (fig. 2) through Durham Canal (South Carolina Water Resources Commission, 1979).

The Cooper River is formed by the confluence of the West and East Branches of the Cooper River at an area referred to as the "Tee" (fig. 2). The West Branch Cooper River flows 18 miles from the tailrace of Pinopolis Dam to the confluence with the East Branch Cooper River at the Tee. This reach is a meandering natural channel bordered by extensive tidal marshes and old rice fields in varying states of disrepair. This area contains large amounts of poorly defined overbank storage and unmeasureable flows through broken levees between the main channel and rice fields. The East Branch Cooper River is a tidal slough throughout its 8-mile reach. On the Cooper River, from the Tee to Flag Creek, industries are located along the west bank of the river and the east bank is dominated by extensive Spartina alterniflora salt marshes. Downstream of Flag Creek, the main channel has been dredged to a depth of $42 \mathrm{ft}$ by the USACOE for navigational purposes (National Oceanic and Atmospheric Administration, 1992). Industries dominate the west bank of the river and the east bank contains numerous dredge-material disposal areas.

The Cooper River is tidally affected throughout its entire reach, and has mean- and springtidal ranges of 5.27 and $6.11 \mathrm{ft}$, respectively, at the Customs House on the lower Cooper River and mean- and spring-tidal ranges of 1.70 and $1.97 \mathrm{ft}$, respectively, at Pimlico on the West Branch Cooper River (National Oceanic and Atmospheric Administration, 1995). Saltwater in the Cooper River extends from the Harbor upstream to several miles below the Tee. The annuial mean flows from Pinopolis Dam were 5,740 and 5,270 ft 3 /s in 1993 and 1994, respectively (Cooney and others, 1996). 
The SCDHEC has classified the Cooper River as SB (tidal saltwater) from the confluence of the Cooper and Wando Rivers to a point approximately 50 miles upstream near the Tee, and has set a dissolved-oxygen water-quality standard for this reach of not less than $4.0 \mathrm{mg} / \mathrm{L}$ (milligrams per liter). From the Tee upstream to U.S. Highway 52, the Cooper River is classified as FW (freshwater) and has a daily average dissolved-oxygen water-quality standard of not less than $5.0 \mathrm{mg} / \mathrm{L}$ with a low of $4.0 \mathrm{mg} / \mathrm{L}$ (South Carolina Department of Health and Environmental Control, 1993).

The Wando River is a tidal slough that tapers from a width of about $2,600 \mathrm{ft}$ at its mouth to a narrow tidal creek in the vicinity of Ward Bridge approximately 21 miles upstream from the confluence with the Cooper River (fig. 2). Saltwater extends throughout the Wando River. The banks of the river are dominated by extensive Spartina alterniflora salt marshes. The tidal ranges in the Wando River amplify as they progress upstream. Mean- and spring-tidal ranges at Hobcaw Point, near the confluence with the Cooper River, are 5.44 and $6.31 \mathrm{ft}$, respectively. As the tide progresses upstream, the mean- and spring- tidal ranges increase to 6.54 and $7.59 \mathrm{ft}$, respectively, at Big Paradise Island (National Oceanic and Atmospheric Administration, 1995). The Wando River is relatively undeveloped, but a shipyard is located near the town of Cainhoy, and a

shipping terminal is located in the lower part of the river. Residential areas are beginning to develop along the east bank.

The Wando River is classified as SA (tidal saltwater) by SCDHEC from its confluence with Cooper River to a point approximately 2.5 miles upstream near the Interstate-526 bridge. Above this point to the headwaters, the Wando River is classified as SFH (shellfish harvesting waters). The dissolved-oxygen water-quality standard for the entire Wando River is a daily average of not less than $5.0 \mathrm{mg} / \mathrm{L}$ with a low of $4.0 \mathrm{mg} / \mathrm{L}$ (South Carolina Department of Health and Environmental Control, 1993).

\section{Acknowledgments}

A study of this complexity required interagency cooperation as well as individual contributions. The authors would like to thank J. Heyward Robinson, Director of the Charleston Harbor Project, for providing the support and coordination of the concerned local interests in the Charleston area; David Chestnut, the late Russell W. Sherer, and Edward "Butch" Younginer of the SCDHEC for their assistance in field sampling, laboratory analysis, and technical support; the permitted dischargers for providing effluent data during the synoptic sampling surveys; and the members of the Advisory Board to the Water-Quality Modeling Project of the Charleston Harbor Project for their annual review of the study. Board members included Dr. Ralph Cheng of the USGS; Dr. David Correl of the Smithsonian Institute; and James Greenfield, of USEPA.

\section{DATA COLLECTION}

Data collected to calibrate and validate the hydraulic and mass-transport models included (1) continuous water-level and specific conductance data at 14 gaging stations, (2) tidal-cycle streamflows at seven locations, (3) channel-geometry data, and (4) discharge data from the hydroelectric, municipal, and industrial facilities. Permitted wastewater-discharge data from treatment plants and monthly water-quality monitoring data were provided by the SCDHEC. 


\section{Continuous Water-Level and Water-Quality Data}

Water-level, dissolved oxygen, water-temperature, and specific conductance data were recorded at 15-minute intervals by data-collection platforms. Water-level gages used float tapes in stilling wells that were interfaced to shaft encoders. The datum for each gaging station was determined by surveys from established benchmarks. The water-quality probes were interfaced to USGS water-quality minimonitors. At most stations water-quality probes were set at the middepth of the water column. To monitor possible stratification in the lower reaches of the Cooper and Wando Rivers, five stations were instrumented with probes near the top and near the bottom of the water column (table 1). Salinity concentrations were calculated from specific conductance data using the algorithms described by Miller and others (1988). Locations of water-level and water-quality gages are shown in figure 3 and listed in table 1 .

\section{Streamflow and Discharge Data}

Streamflow data for the calibration and validation of the hydraulic model were obtained either from field measurements or model simulations using existing models of subreaches of the study area. Streamflows were measured by the USGS at five locations on the Wando River and its tributaries (fig. 4; table 2). Streamflows were measured by the University of South Carolina School of Public Health at two locations on Goose Creek. Streamflows for four locations on the Cooper River were simulated with the documented USGS BRANCH model for use in calibration and validation of the model in this study (Bower and others, 1993).

Daily records of the water withdrawals from the Bushy Park Reservoir and discharges to the Cooper River were obtained from industries. Daily and hourly discharge rates from Pinopolis Dam were obtained from South Carolina Public Service Authority.

\section{Channel-Geometry Data}

Channel-geometry data for the Wando River were obtained from field surveys by USGS personnel. Channel-geometry data for the Cooper River above Goose Creek and for Goose Creek were obtained from the previous modeling efforts. Channel-geometry data for the Cooper River below Goose Creek and the Wando River below the Interstate 526 bridge were obtained from National Oceanic and Atmospheric Administration nautical charts (National Oceanic and Atmospheric Administration, 1992).

\section{SIMULATION OF WATER LEVEL, STREAMFLOW, AND MASS TRANSPORT}

To obtain accurate hydrodynamic data sets for the water-quality model, it is necessary to simulate water level, streamflow, and mass transport of a conservative constituent in the Cooper and Wando Rivers. The one-dimensional, unsteady-flow model, BRANCH, was used to simulate the hydraulic properties within the system. Because BRANCH does not simulate mass transport, it was necessary to use the one-dimensional, unsteady-transport model, BLTM, to simulate the mass transport in the system. 
Table 1. Continuous water-level and water-quality stations in the vicinity of Charleston Harbor, S.C., and the constituents monitored

[WL, water level; T, water temperature; DO, dissolved oxygen; SC, specific conductance]

\begin{tabular}{|c|c|c|}
\hline $\begin{array}{c}\text { Station } \\
\text { number } \\
\text { (fig. 3) }\end{array}$ & Station name & Constituents \\
\hline 021720011 & Lake Moultrie Tailrace near Moncks Corner, S.C. & WL, T, DO, SC \\
\hline 02172019 & $\begin{array}{l}\text { West Branch Cooper River at Mepkin Abbey } \\
\text { near Cordesville, S.C. }\end{array}$ & WL, SC \\
\hline 02172037 & East Branch Cooper River near Goose Creek, S.C. & WL, T, DO, SC \\
\hline 02172040 & Back River at Dupont Intake near Kittredge, S.C. & WL, T, DO, SC \\
\hline 02172050 & Cooper River near Goose Creek, S.C. & $\mathrm{WL}, \mathrm{T}^{1}, \mathrm{DO}^{1}, \mathrm{SC}^{1}$ \\
\hline 02172053 & Cooper River at Mobay near North Charleston, S.C. & WL, T, DO, SC \\
\hline 02172066 & Goose Creek near Goose Creek, S.C. & WL \\
\hline 021720675 & Cooper River at Army Depot near North Charleston, S.C. & $\mathrm{WL}, \mathrm{T}^{1}, \mathrm{DO}^{1}, \mathrm{SC}^{1}$ \\
\hline 021720694 & Wando River above Cainhoy, S.C. & WL, T, DO, SC \\
\hline 021720695 & Guerin Creek above Cainhoy, S.C. & WL, T, DO, SC \\
\hline 021720696 & Wando River at Cainhoy, S.C. & $\mathrm{WL}, \mathrm{T}^{1}, \mathrm{DO}^{1}, \mathrm{SC}^{1}$ \\
\hline 021720698 & Wando River above Mt. Pleasant, S.C. & $\mathrm{WL}, \mathrm{T}^{1}, \mathrm{DO}^{1}, \mathrm{SC}^{1}$ \\
\hline 021720710 & $\begin{array}{l}\text { Cooper River at Customs House at Charleston, S.C. } \\
\text { (Auxiliary) }\end{array}$ & $\mathrm{T}^{1}, \mathrm{DO}^{1}, \mathrm{SC}^{1}$ \\
\hline${ }^{2} 021720711$ & Cooper River at Customs House at Charleston, S.C. & WL \\
\hline
\end{tabular}

${ }^{1}$ Near-top and near-bottom probes.

${ }^{2}$ Station at same location as 021720710 . 


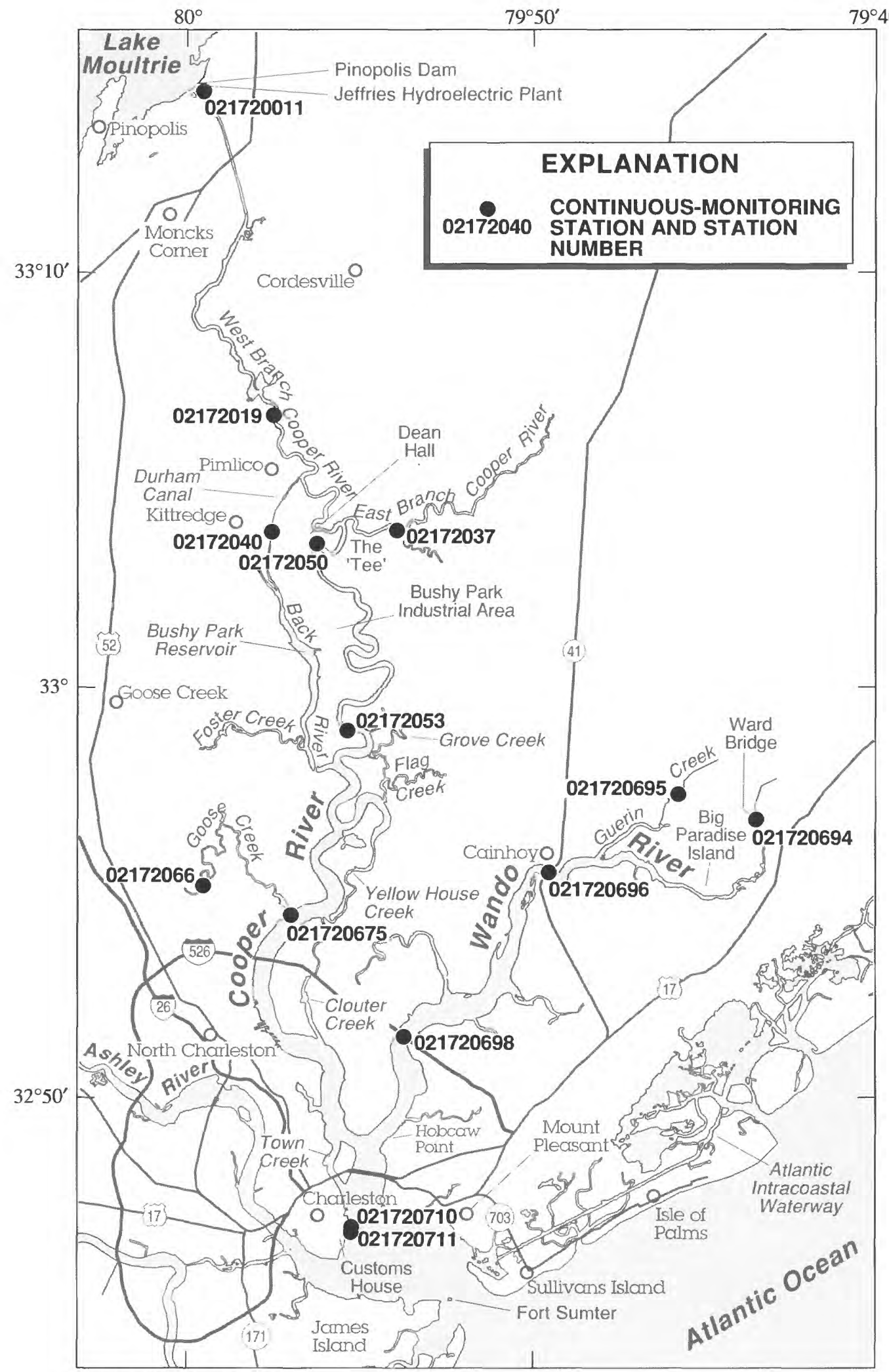

Base from U.S. Geological Survey

1:100,000 scale Digital Line Graphs

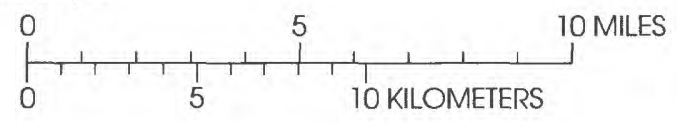

Figure 3. Location of continuous-monitoring stations on the Cooper and Wando Rivers and their tributaries, S.C. 


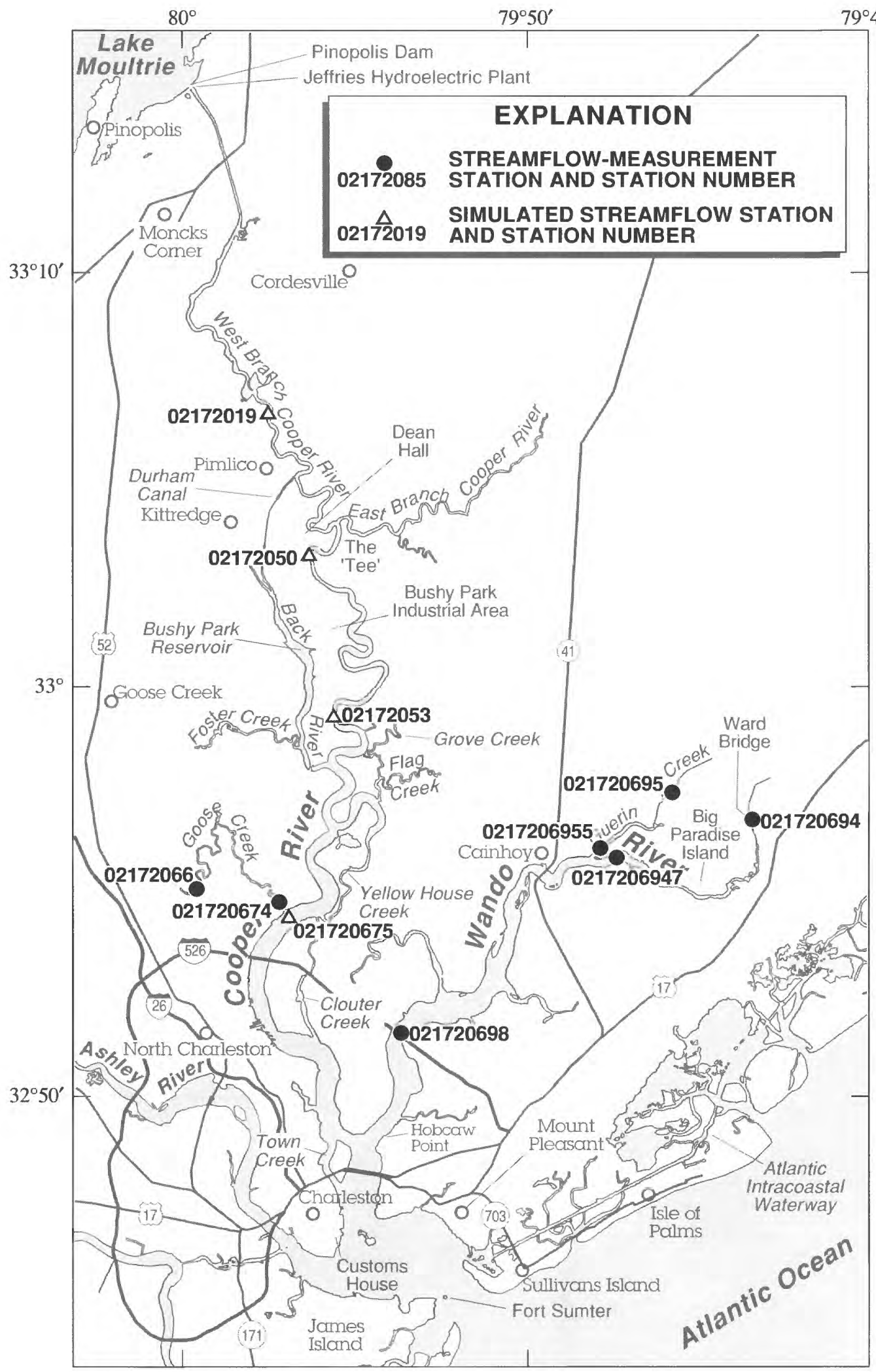

Base from U.S. Geological Survey 1:100,000 scale Digital Line Graphs

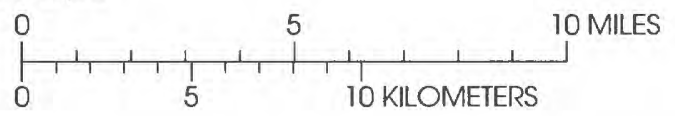

Figure 4. Location of streamflow stations on the Cooper and Wando Rivers and their tributaries, S.C. 
Table 2. Streamflow stations in the vicinity of Charleston Harbor, S.C., and measurement dates [M, measured; S, simulated; USGS, U.S. Geological Survey; USC, University of South Carolina]

\begin{tabular}{|c|c|c|c|c|}
\hline $\begin{array}{c}\text { Station } \\
\text { number } \\
\text { (fig. 4) }\end{array}$ & Station name & $\begin{array}{l}\text { Data } \\
\text { type }\end{array}$ & $\begin{array}{c}\text { Data } \\
\text { source }\end{array}$ & Date \\
\hline 02172019 & Cooper River at Mepkin Abbey near Cordesville, S.C. & $\mathrm{S}$ & USGS & $\begin{array}{l}07 / 30 / 92 \\
09 / 13 / 92\end{array}$ \\
\hline 02172050 & Cooper River near Goose Creek, S.C. & $\mathrm{S}$ & USGS & $\begin{array}{l}07 / 30 / 92 \\
09 / 13 / 92\end{array}$ \\
\hline 02172053 & Cooper River at Mobay near North Charleston, S.C. & $\mathrm{S}$ & USGS & $\begin{array}{l}07 / 30 / 92 \\
09 / 13 / 92\end{array}$ \\
\hline 02172066 & Goose Creek near Goose Creek, S.C. & M & USC & $12 / 04 / 92$ \\
\hline 021720674 & Goose Creek at Army Depot near Goose Creek, S.C. & M & USC & $\begin{array}{l}10 / 03 / 92 \\
12 / 04 / 92\end{array}$ \\
\hline 021720675 & Cooper River at Army Depot near North Charleston, S.C. & $\mathrm{S}$ & USGS & $\begin{array}{l}07 / 30 / 92 \\
09 / 13 / 92\end{array}$ \\
\hline 021720694 & Wando River above Cainhoy, S.C. & M & USGS & $\begin{array}{l}07 / 30 / 92 \\
09 / 24 / 92\end{array}$ \\
\hline 0217206947 & Wando River at Wagner Point above Isle of Palms, S.C. & M & USGS & $\begin{array}{l}07 / 30 / 92 \\
09 / 24 / 92\end{array}$ \\
\hline 021720695 & Guerin Creek above Cainhoy, S.C. & M & USGS & $\begin{array}{l}07 / 30 / 92 \\
09 / 24 / 92\end{array}$ \\
\hline 0217206955 & Guerin Creek at Cat Island near Isle of Palms, S.C. & M & USGS & $\begin{array}{l}07 / 30 / 92 \\
09 / 24 / 92\end{array}$ \\
\hline 021720698 & Wando River above Mount Pleasant, S.C. & M & USGS & $\begin{array}{l}07 / 30 / 92 \\
09 / 24 / 92\end{array}$ \\
\hline
\end{tabular}




\section{Simulation of Water Level and Streamflow}

The BRANCH model is a one-dimensional, unsteady-flow computer model for simulation of streamflow in interconnected channels (Schaffranek and others, 1981). The model solves the one-dimensional equations of continuity and motion:

$$
\begin{gathered}
B \frac{\partial Z}{\partial t}+\frac{\partial Q}{\partial x}-q=0 \\
\frac{\partial Q}{\partial t}+\frac{\partial\left(\beta Q^{2} / A\right)}{\partial x}+g A \frac{\partial Z}{\partial x}+\frac{g k}{A R^{4 / 3}} Q|Q|-q u^{\prime}-\xi B_{c} U_{a}^{2} \cos \alpha=0
\end{gathered}
$$

where
$B \quad$ is the total channel top width, in feet;
$Z \quad$ is the stage, in feet;
$t \quad$ is the time, in seconds;
$Q \quad$ is the discharge, in cubic feet per second;
$x \quad$ is the longitudinal distance along the channel, in feet;
$q \quad$ is the lateral side-channel flow, in cubic feet per second, per foot;
$\beta \quad$ is the dimensionless momentum coefficient;
$A$ is the cross-sectional area, in square feet;
$g \quad$ is the gravitational acceleration constant, in feet per second per second;
$k \quad$ is a function defining flow-resistance;
$R \quad$ is the hydraulic radius, in feet;
$u^{\prime} \quad$ is the $\mathrm{x}$-component of the lateral side-channel flow velocity, in feet per second;
$\xi \quad$ is the dimensionless wind resistance coefficient;
$B_{c} \quad$ is the top width of the conveyance part of the cross section, in feet, and
$U_{a}$ is the wind velocity in feet per second, occurring at an angle $\alpha$ from the positive $\mathrm{x}$-axis.

The flow-resistance function is expressed as $k=(\mathrm{eta} / 1.486)^{2}$, where eta is a flow-resistance coefficient.

In the derivation of equations 1 and 2 , it is assumed that the flow is essentially homogeneous in density. The channel is assumed (1) to be reasonably straight, (2) to be of simple geometry, such as having a rectangular or trapezoidal shape, and (3) to have a mild and uniform gradient. Approximate solutions for the nonlinear partial-differential unsteady-flow equations are obtained by finite-difference techniques (Schaffranek and others, 1981). A weighted four-point finitedifference approximation is used in the BRANCH model. 
In the model, rivers are represented as a series of cross sections and channel lengths, which define segments, junctions, and branches. Channel-geometry data that characterize the conveyance, area, width, and storage capacity at each cross section are input into the model. A segment is defined by an upstream and a downstream cross section and the distance between them. A group of segments that is separated by junctions is called a branch. The beginning or ending junction of a branch with no continuing branches is known as an external boundary. Water-level or streamflow data are input at the external boundaries as boundary conditions for the model. All other water levels and streamflows are computed at cross sections. An idealized BRANCH network model schematization is shown in figure 5.

There are limitations to applying a one-dimensional model to a complex tidal system. The BRANCH model is appropriate to apply to the Cooper and Wando Rivers and the model has been successfully applied to similar estuarine systems. Although parts of the Cooper River are considered partially stratified, there are extended periods when there is very little stratification. The complex channel geometry of old rice fields and tidal marshes can be simplified in BRANCH as large storage areas that fill and drain with each tidal cycle. BRANCH, unlike other riverine models, also can simulate the converging and branching of interconnected channels. Bower and others (1993), as discussed previously, applied the model to the Cooper River and Bushy Park Reservoir to analyze retention times in the reservoir. Drewes and Conrads (1995) applied the BRANCH model and BLTM to the Waccamaw and Pee Dee Rivers and the Atlantic Intracoastal Waterway to determine the assimilative capacity of the system. Weiss and others (1994) applied the BRANCH and BLTM models to the tidal Hudson River in New York to analyze streamflow and chloride transport.

The BRANCH model of the Cooper River by Bower and others (1993) was modified before it was included in the model of the Cooper and Wando Rivers. The Cooper model included the Bushy Park Reservoir and Foster Creek, which is hydraulically connected to the Cooper River through the Durham Canal. Because Foster Creek and Bushy Park Reservoir are not receiving waters for permitted effluent discharges, it was decided to remove these branches from the model and use simulated flows from the original model as an external boundary at Durham Canal.

The BRANCH model for the Cooper and Wando Rivers was schematized using 37 branches, 23 internal junctions, 156 cross sections, and 10 external boundaries (fig. 6). The BRANCH model of the Cooper River by Bower and others (1993) used water-level data for the upstream boundary at Pinopolis Dam (station 021720011). To facilitate the use of the model of the Cooper and Wando Rivers for various water-resource management scenarios involving different flow releases from the Pinopolis Dam, it was decided to use flow data for the upstream boundary. Flow data for Pinopolis Dam were provided by the South Carolina Public Service Authority. Water-level data were used at Goose Creek near Goose Creek (02172066), and Cooper River at the Customs House (021720711). Flow boundaries of zero flow were used at upstream boundaries of five tidal creeks and sloughs where freshwater inflow into the system is negligible.

Numerical instability was observed in the model near the upper boundaries of Guerin Creek and the Wando River when water-level data were used at these boundaries. The instability can be attributed to the large difference in streamflows between these upper reaches and lower reaches (500 to $150,000 \mathrm{ft}^{3} / \mathrm{s}$, respectively). Variables in the model that had the greatest effect in controlling the numerical instability were the streamflow convergence criterion (QQTOL), waterlevel convergence criterion (ZZTOL), finite-difference weighting factor for the spatial derivatives 


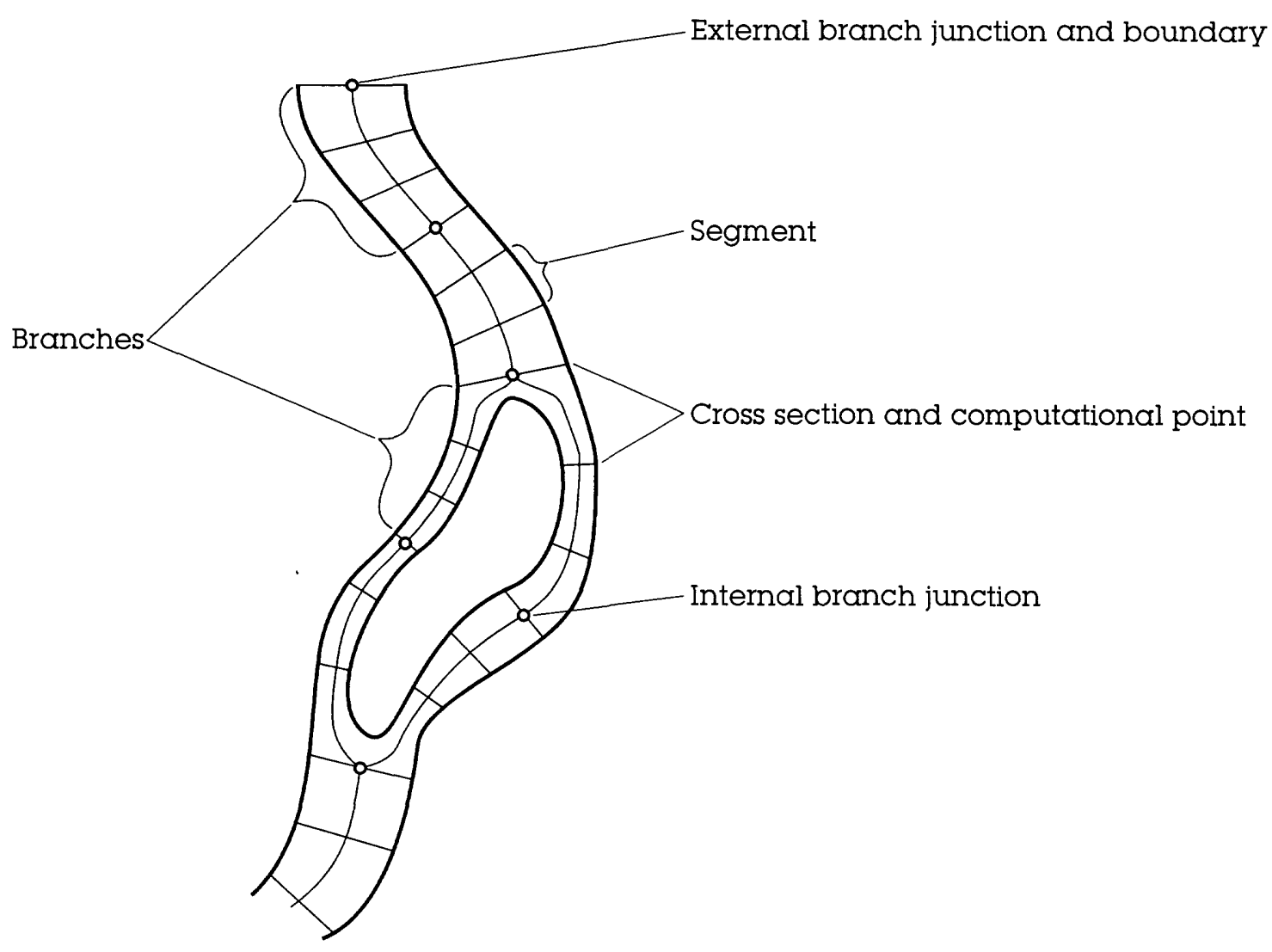

Figure 5. Idealized BRANCH model schematization.

(THETA), and the finite-difference weighting factor for function values in the equation of motion (CHI). These variables were set to the following values; $800 \mathrm{ft}^{3} / \mathrm{s}, 0.025 \mathrm{ft}, 1.00$, and 1.00 , respectively. To help stabilize the upper reaches of the model, the boundaries were extended 4 miles upstream on the Wando River and 3 miles on Guerin Creek to account for tidal marsh storage in these reaches, and a zero-flow boundary was used instead of water level. The boundaries of the hydraulic model and their data types and sources are listed in table 3 and shown in figure 6.

The model was tested for convergence to determine the optimum simulation time step and space step (the distance between cross sections) for the simulations. A finite-difference solution to the partial-differential governing equations is convergent if the numerical solution approaches the true solution of the differential equation as the numerical time step and space step are decreased (Smith, 1985). Convergence can be tested by repeated simulations of the model with a fixed set of boundary conditions for successively smaller computational time steps and space steps. The model is convergent if no further change in the model results is observed as the time step and space step are refined (Thompson, 1992). 


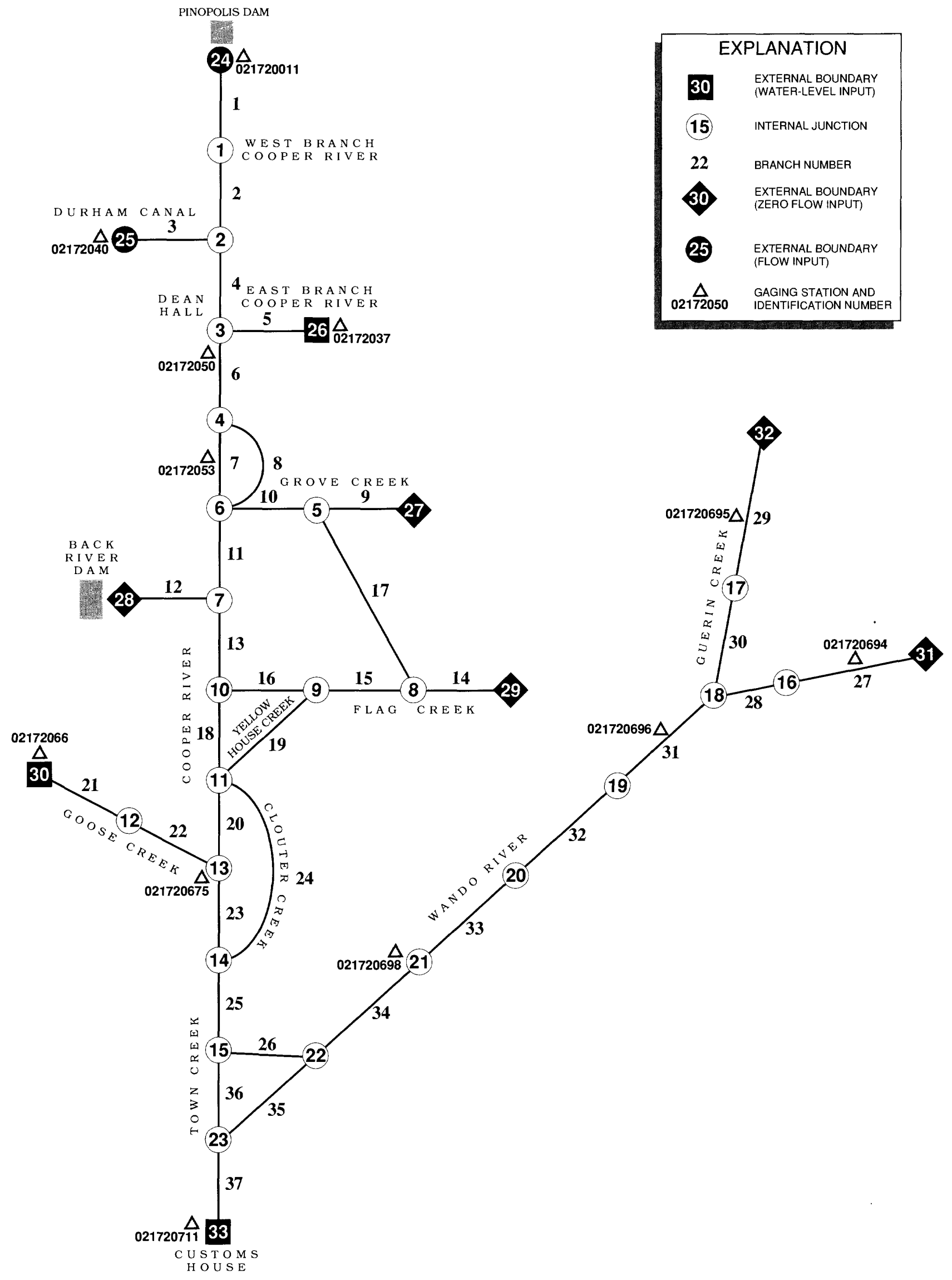

Figure 6. BRANCH model schematization for the Cooper and Wando Rivers, S.C. 
Table 3. Boundary locations, data types, data sources, and data frequency

[min, minute; USGS, U.S. Geological Survey; --, no data]

\begin{tabular}{lclcc}
\hline \multicolumn{1}{c}{ Boundary location } & $\begin{array}{c}\text { External } \\
\text { boundary } \\
\text { number } \\
\text { (fig. 6) }\end{array}$ & Data type & Data source & $\begin{array}{c}\text { Data } \\
\text { frequency }\end{array}$ \\
\hline Pinopolis Dam Tailrace & 24 & Flow & $\begin{array}{c}\text { South Carolina } \\
\text { Public Service Authority }\end{array}$ & 60 min \\
Durham Canal & 25 & Flow & Simulated using BRANCH & 15 min \\
East Branch Cooper River & 26 & Water level & USGS Station 02172037 & 15 min \\
Grove Creek & 27 & Flow $=0$ & -- & -- \\
Cooper River by Back River Dam & 28 & Flow $=0$ & -- & -- \\
Flag Creek & 29 & Flow $=0$ & -- & -- \\
Goose Creek & 30 & Water level & USGS station 02172066 & 15 min \\
Wando River & 31 & Flow $=0$ & -- & -- \\
Guerin Creek & 32 & Flow $=0$ & -- & -- \\
Cooper River at Customs House & 33 & Water level & USGS Station 021720711 & 15 min \\
\hline
\end{tabular}

Model simulations were generated for successively smaller computational time steps of 60 , 30,15 , and 7.5 minutes. Significant differences in model results occurred between the 60- and 30-minute time steps and between the 30- and 15-minute time steps. The differences between the 15- and 7.5-minute time steps were considered insignificant. Therefore, a 15-minute time step was used in the model. Similar convergence testing was performed on the space step using the preliminary model application to the Wando River. Cross sections defining the system were spaced at approximately 4-, 2-, and 1-mile intervals. No significant differences in the model results were observed. A space step of 1 to 2 miles was used in the model.

\section{Simulation of Mass Transport}

The BLTM was used to simulate the mass transport in the Cooper and Wando Rivers and their tributaries. The BLTM solves the convective-dispersion equation by using a Lagrangianreference frame in which the computational nodes move with the flow (Jobson and Schoelhamer, 1987). In the Lagrangian-reference frame, the continuity of mass equation is:

$$
\frac{\partial C}{\partial t}=\frac{\partial}{\partial \xi}\left[D \frac{\partial C}{\partial \xi}\right]+S+\Phi+K((C-C R))
$$


where

$C \quad$ is the concentration, in milligrams per liter;

$t$ is time, in seconds;

$\xi \quad$ is the Lagrangian-distance coordinate, in feet;

$D$ is the longitudinal dispersion coefficient, in square feet per second;

$S \quad$ is the rate of production of the concentration, which is independent of the concentration (zero-order production rate), in milligrams per liter per second;

$\Phi \quad$ is the rate of change in concentration due to tributary inflow, in milligrams per liter per second;

$K \quad$ is the rate of production of the constituent, in per second, and

$C R$ is the equilibrium concentration (that is, the concentration at which the internal production ceases), in milligrams per liter.

The Lagrangian-distance coordinate, $\xi$, is given by

$$
\xi=x-x_{o}-\int_{t_{o}}^{t} u d t
$$

where

$x \quad$ is the Eulerian (stationary) distance coordinate along the river, in feet;

$x_{o} \quad$ is the location of the parcel of water at time $t_{o}$, and

$u \quad$ is the cross-sectional mean stream velocity, in feet per second.

The BLTM uses a dimensionless dispersion factor in the Lagrangian transport solutions. The dispersion factor is inversely proportional to the square of the stream velocity. The factor is defined as:

$$
\mathrm{D}_{\mathrm{f}}=\frac{\mathrm{D}}{\Delta \mathrm{t} \mu^{2}}
$$

where

$\mathrm{D}_{\mathrm{f}} \quad$ is dispersion factor, dimensionless;

$\mathrm{D}$ is dispersion rate, in square feet per second;

$\Delta \mathrm{t} \quad$ is simulation time step, in seconds; and

$\mu \quad$ is the representative stream velocity, in feet per second.

The advantage of the Lagrangian-reference frame, especially in a mesotidal environment such as the Cooper and Wando Rivers, is that there is minimal numerical dispersion. An assumption of the BLTM is that parcels of water are completely mixed and that volumes are affected only by tributary flows. The variation of concentrations in space and time in a river reach is approximated by solving equation (3) for a series of parcels spaced along the river at intervals approximately equal to $\mu \Delta \mathrm{t}$. The concentration at any point is the concentration of the parcel at 
that point. The assumption of completely mixed parcels may cause interpolation errors when determining the concentration of a given point. The accuracy of a Lagrangian model, as compared to an Eulerian model, is that this interpolation error applies only to the output computations. The grid concentration is not used in further computations, and therefore, the error is not compounded. However, in an Eulerian model, similar interpolation errors made at every time step and grid concentrations are used as the basis for all further computations and result in compounding errors (Jobson, 1981). In BLTM, some numerical dispersion is introduced into the solution scheme at internal junctions.

The advantages of the Lagrangian approach, as outlined above, are (1) the scheme is very accurate in modeling the convection and dispersion terms in comparison to the Eulerian approach (Jobson, 1980; Thomson and others, 1984); (2) the Lagrangian model is stable for any time step (Jobson, 1981); (3) the computer code for the algorithms is short; and (4) the conceptual model directly represents the actual transport processes.

The BLTM for the Cooper and Wando Rivers is schematized using 30 branches, 10 external boundaries, and 16 internal junctions (fig. 7). The schematization of the BLTM for the Cooper and Wando Rivers differs from the BRANCH schematization in two significant ways. First, internal junctions in the BRANCH model that do not have branching segments were removed to minimize numerical dispersion. Second, a zero-flow boundary condition was not used for the upper boundaries on the Wando River and Guerin Creek. Boundary-constituent concentrations are input into BLTM as a flux, so boundary data must be associated with a flow to be brought into the model domain. Because salinity extends throughout the Wando River and Guerin Creek, the boundary locations were set at the locations of gaging stations 021720694 and 021720695 , respectively (figs. 3,7 ). In addition, salinity concentrations are input into the model at the lower boundary (station 021720710) (figs. 3, 7). Although salt extends up Goose Creek, no continuous salinity data were available for the periods simulated.

As stated previously, the BRANCH model was extended in the upper reaches of the Wando River and Guerin Creek to accommodate the zero-flow boundary. The flow field generated by BRANCH of the hydraulic properties for every cross section had to be modified so as not to include the extended upper reaches. The BLTM was checked for continuity at these upper boundaries to ensure that mass was being conserved. The BLTM was run using a 15-day tidal flow field and the initial conditions and boundary salinity data were set at $20 \mathrm{ppt}$. The model predicted a salinity concentration of $20 \mathrm{ppt}$ for the 15-day period in every branch and therefore was conserving mass.

\section{Calibration and Validation of Water Level, Streamflow, and Mass Transport}

Measured water-level, streamflow, and calculated salinity data collected during the summer and fall of 1992 were used to calibrate the BRANCH and BLTM models. Calibration was accomplished by adjusting flow resistance coefficients, gage datums, cross-sectional areas, storage volumes, and dispersion-rate model parameters until simulated and measured (or calculated) values agreed with one another. Because the model will ultimately be used to simulate the fate and transport of conservative and non-conservative constituents, emphasis was placed on the salinity-transport simulations during the calibration and validation. 


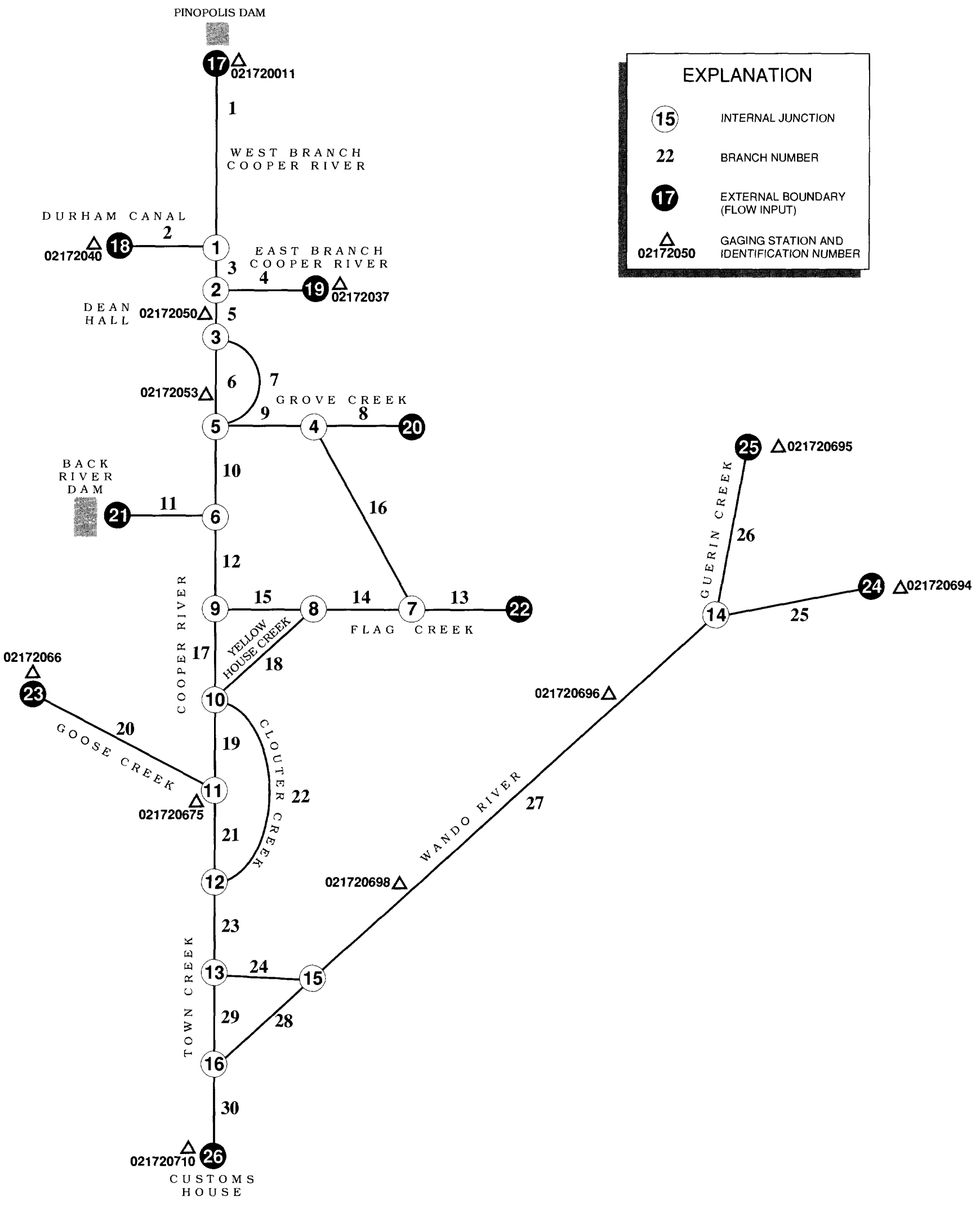

Figure 7. Branched Lagrangian Transport Model schematization for the Cooper and Wando Rivers, S.C. 
Results of the flow-model calibration and validations are presented in hydrographs of simulated and measured water level and streamflow and results of the transport model are presented in hydrographs of simulated and calculated salinity. Summary statistics were generated to quantify the error of the calibration and validation simulations and are presented in tabular form. Summary statistics for water-level simulations include timing error, mean of the residuals, and the standard deviation of the residuals. Quite often, the model simulates the shape of the measured data but has a timing error where the data are simulated earlier or later than the measured data. The timing error was computed by correlating measured values with the simulated values offset forward or backwards in time. The time period having the highest correlation coefficient was assumed to be the timing error of the simulated hydrograph. The mean and standard deviation of the residuals were computed after the adjustment for the timing error. An adjustment was made for the timing error, because the modeled results maintaining the shape of the measured data are acceptable, even with moderate timing errors. The mean of the residuals is a measure of the bias of the simulation and is an indication of how much higher or lower the simulated values are than the measured values. The standard deviation of the residuals is a measure of the scatter of the residuals about the mean of the residuals.

For the streamflow simulations, the timing error was computed by the same method used for the water-level simulations. After correcting the simulations for the timing error, an index of the mean of the residuals (given as a percentage) was computed by multiplying 100 times the mean of the residuals divided by the mean of the absolute values of the measured streamflows. Normally, percent residuals can be scaled by using logarithms of streamflows, but logarithms can not be used for negative streamflows. Percent residuals also could be scaled by the mean streamflow, but the mean for tidal streamflows is zero or near zero. Therefore, the mean of the absolute values of the streamflows was used to give an indication of the magnitude of streamflows being measured at the location of the simulation. The index is not a true percentage, because it will not be representative throughout the ranges of streamflows of the simulations (especially when those values are low or passing through zero). However, the index of the mean of the residuals does indicate whether the model is over- or under-simulating the measured streamflow and is a usable index for comparing simulations both at one station and between stations. An index of the standard deviation of the residuals (also given as a percentage) was computed by multiplying 100 times the standard deviation of the residuals divided by the mean of the absolute values of the measured streamflow. As with the index of the mean of the residuals, the index is not a true percentage but is a usable index for comparing the scatter of the simulations.

The mean value should be considered in evaluating the magnitude of the indices of the mean of the residuals or standard deviation of the residuals. For example, a large value for the index of the mean of the residuals for a small mean streamflow does not have the effect on the transport in the main stem as the same value associated with a large mean streamflow. The mean absolute values of measured streamflow also are listed with the statistical summaries.

For the salinity simulations, indices of mean residuals and the standard deviation of residuals were computed by the same method used for streamflow simulations, except that it was not necessary to take the absolute values of the calculated salinities. The mean values of measured calculated salinities also are listed with the statistical summaries. 
The datasets used for calibration and validation consisted of measured tidal-cycle streamflows for five locations on the Wando River and Guerin Creek from July 30 and September 24, 1992. Tidal-cycle streamflows were not measured on the Cooper River during these periods. To evaluate the performance of the Cooper River part of the Cooper-Wando model, concurrent simulated tidal-cycle streamflows for four sites on the Cooper River were made using the existing Cooper River model (Bower and others, 1993) (table 2, fig. 4) for July 30 and September 13, 1992. In addition to the streamflow measurements, continuous water-level data at six locations on the Cooper and Wando Rivers and salinity data at four locations on the Cooper and Wando Rivers were used. Three streamflow measurements made on Goose Creek by McKellar and others (1995) also were compared using the model of the Cooper and Wando Rivers.

The preliminary calibrations of the mass-transport model of the Cooper and Wando Rivers were not satisfactory. Although the simulated streamflows and water levels agreed with the measured streamflows and water levels, the simulated salinity concentrations were much lower than the observed concentrations. At station 02172053 on the Cooper River (fig. 3), where the salinity concentration is normally between 0 and $10 \mathrm{ppt}$, salt was flushing out of the system after the first tidal-cycle. Adjustments to the dispersion factor in the BLTM did not significantly improve the predicted salinity concentration. The hydraulic model simulated too much ebb tide (positive flow) and not enough flood tide (negative flow) to maintain the salinity concentrations in the vicinity of the salt front on the Cooper River near station 02172053. Farther downstream, at station 021720675 , where the tidal range of calculated salinity concentrations was approximately 6 to $15 \mathrm{ppt}$, the simulated concentrations were between 2 and 4 ppt.

Various approaches were taken to adjust the hydraulic model to simulate a greater flood tide while still maintaining the generally good simulation of water levels and streamflows. A lower roughness coefficient (eta) was used for the flood tide than the ebb tide. Fifteen-day salinity simulations then showed a steady propagation of the salinity front upstream beyond the observed location of the salinity front. Channel dimensions were increased to simulate a greater flood tide, but without satisfactory results. Finally, a gage datum adjustment of $0.45 \mathrm{ft}$ was added to the downstream boundary at station 021720711 . The transport model showed a great sensitivity to the downstream datum. The published gage datum is $17.12 \mathrm{ft}$ below sea-level. Using a datum of $-16.67 \mathrm{ft}$ for the downstream boundary improved the comparison between the simulated and calculated salinity concentrations in the Cooper and Wando Rivers, because it effectively decreased the slope in the system. The effect of a gage-datum adjustment of $0.45 \mathrm{ft}$ at the downstream boundary on the simulated salinity concentration at stations 02172053 and 021720675 is shown in figure 8 .

Without the datum correction, the salinity in the Mobay reach (near station 02172053) disappeared from the system in only a few tidal-cycles. With a $0.45 \mathrm{ft}$ correction to the downstream boundary, the salinity remained in the Mobay reach of the model. Similar results occurred downstream at the Army Depot reach (near station 021720675). Without the datum correction, the model underpredicted the calculated salinity concentration by $10 \mathrm{ppt}$. By applying the $0.45 \mathrm{ft}$ correction, the simulated salinity concentrations were within the range of the calculated salinity concentrations. 


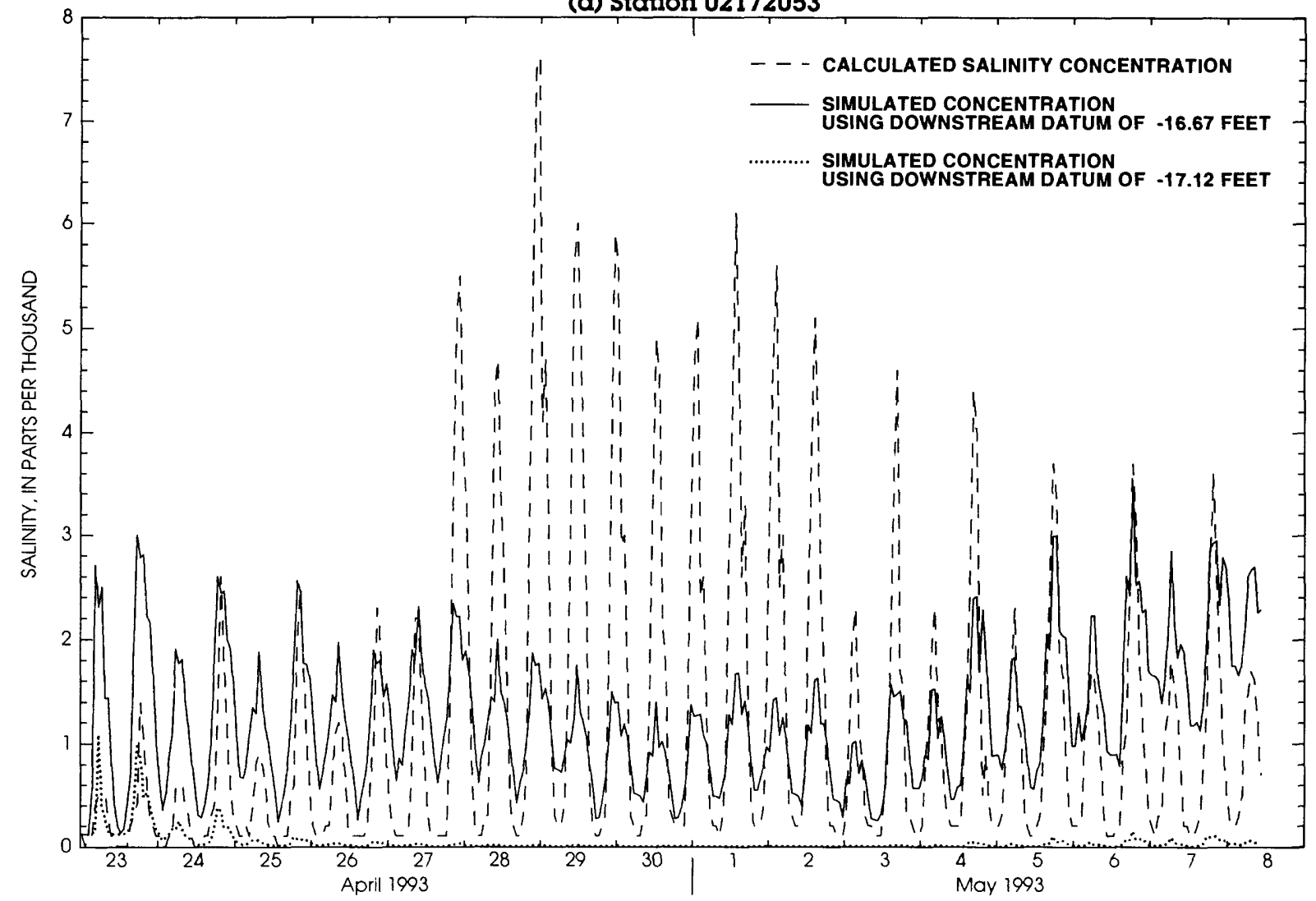

(b) Station 021720675

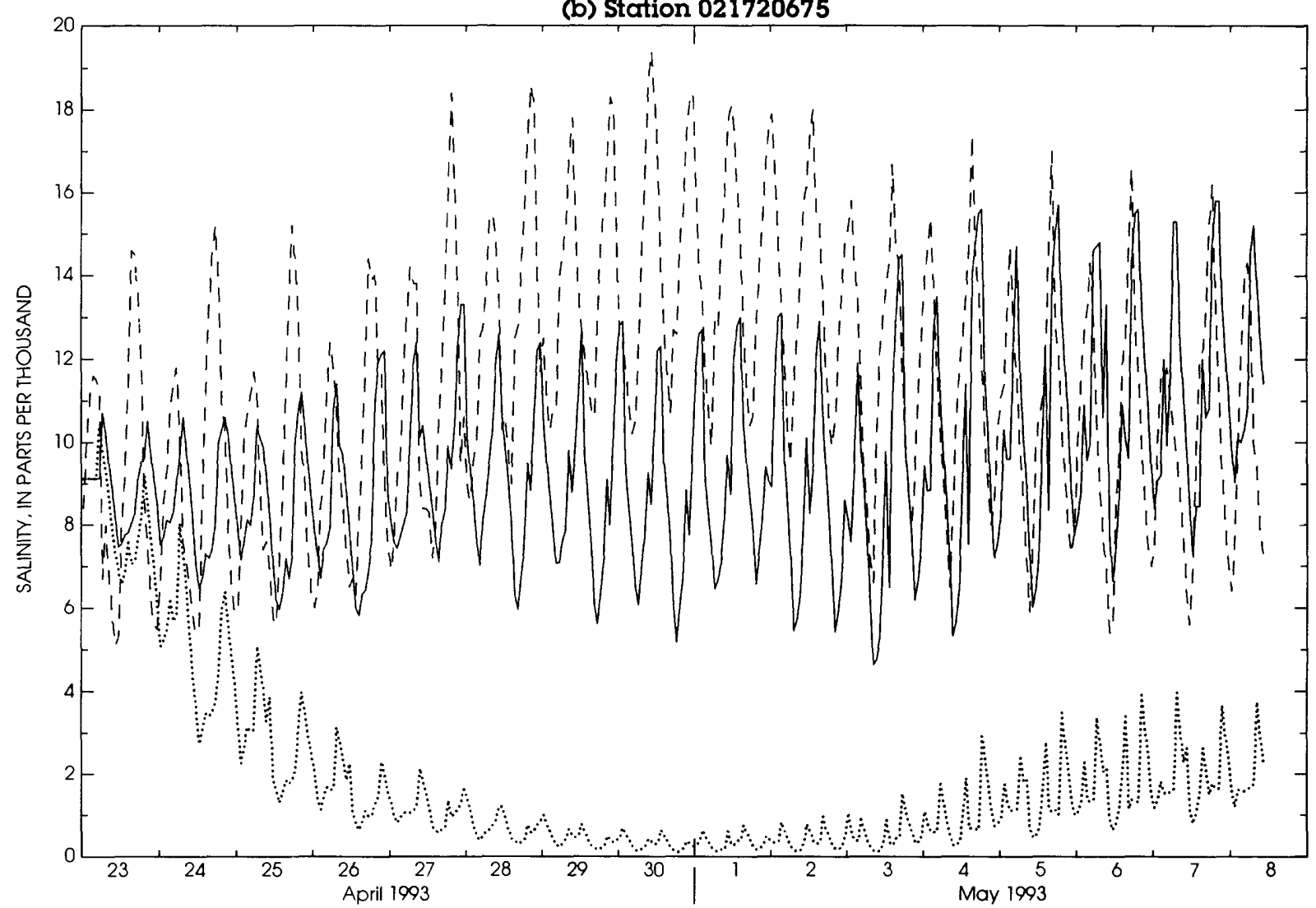

Figure 8. Sensitivity of simulated salinity concentrations to changes in downstream datum adjustment for two locations on the Cooper River, S.C., April 23 to May 8, 1993. 
The length of the modeled system should be considered when evaluating the magnitude of the datum adjustment. The length of the Cooper River from the Pinopolis Dam to the Customs House is 47 miles, and the length of the Wando River from Ward Bridge to the confluence with the Cooper River is 21 miles. A datum adjustment of $0.45 \mathrm{ft}$ is an adjustment of $0.000002 \mathrm{ft} / \mathrm{ft}$ (foot per foot) over the length of the Cooper River and $0.000004 \mathrm{ft} / \mathrm{ft}$ over the length of the Wando River.

The use of the datum adjustment on the lower boundary compensates for limitations in the BRANCH model and its application to the Cooper and Wando Rivers. The BRANCH model does not account for baroclinic pressure gradients that arise because of density differences throughout the system. However, steady-state density differences can be put into the model. Water densities were input into the model with the branches from the upper boundary to the Tee set for freshwater and the branches below the Tee set for gradually increasing densities from freshwater to $40 \mathrm{ppt}$ at the lower boundary. After inputting the steady-state density differences into the model, it was still necessary to apply a final datum adjustment of $0.45 \mathrm{ft}$ to the model. Additionally, the schematization of the channel geometry, with cross sections spaced approximately every 1 to 2 miles, does not represent all the smaller constrictions and expansions that account for energy losses through the system. In addition, the effects of wind on the system were not included in the model.

The widths of the storage areas adjacent to the Wando River were varied to calibrate the hydraulic model. The Wando River is characterized by extensive Spartina alterniflora marshes with meandering tidal creeks that extend for several miles. During every flood tide, these creeks and marshes are inundated with a few feet of water that drain into the river on the subsequent ebb tide. The BRANCH model routes water into "dead" storage. It is considered dead storage because water only moves laterally into and out of storage and there is no net upstream or downstream flow of water over the storage area. Agreement between the simulated and measured streamflow was obtained by increasing the storage widths from initial estimates.

Preliminary attempts were made to incorporate small tidal creeks into the model. The small channel geometry and corresponding streamflows, as compared to the mainstem, created instability problems in the model. Because the intent of the model was to evaluate constituent transport in the mainstem, it was decided that the water moving in and out of the tidal creeks would be compensated for by increasing the storage widths along the mainstem of the Wando River. It was not necessary to do this on the Cooper River and Goose Creek, because instability problems were not observed in those branches of the model.

The $0.45 \mathrm{ft}$ datum adjustment to the downstream boundary had dramatic effects on the salinity transport, but not without adversely affecting the water-level and streamflow simulations (fig. 9). At stations 02172053 and 021720675, the water-level simulations using the datum adjustment increased the height of the high- and low-slack tides by the amount of the adjustment (figs. 9a, 9c). The datum adjustment decreased the slope of the system, and therefore decreased the amount of ebb tide (positive flow) and increased the amount of flood tide (negative flow). Comparison of the streamflow hydrographs for the two stations on the Cooper River shows that the datum correction had a greater effect on the flood tide than the ebb tide (figs. 9b, 9d). 


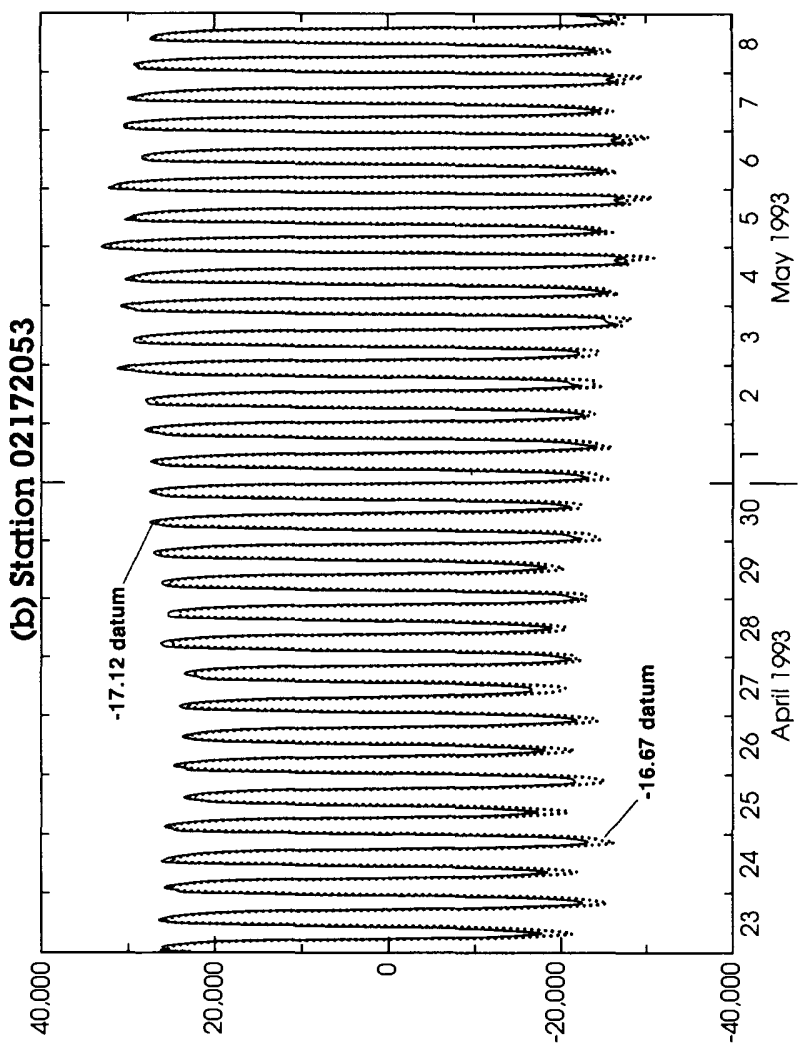

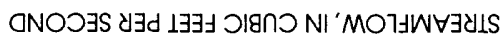

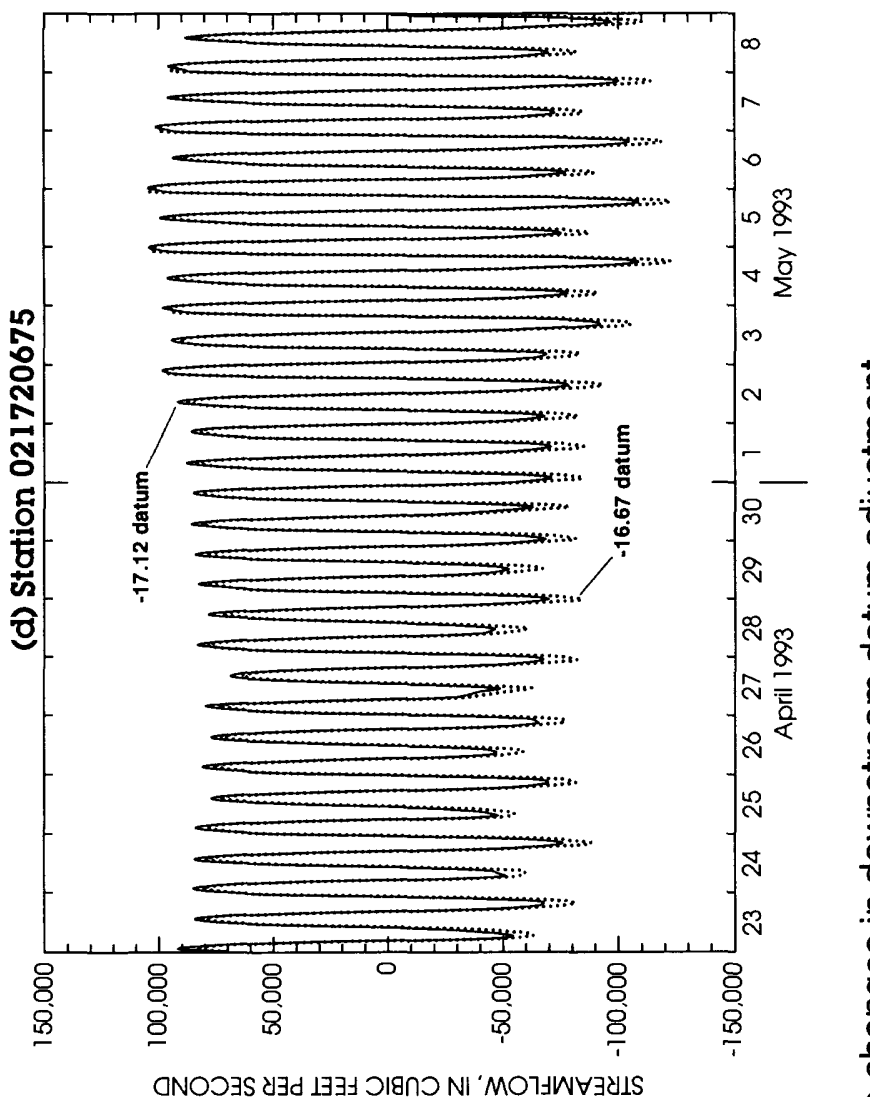

ONOOJS y

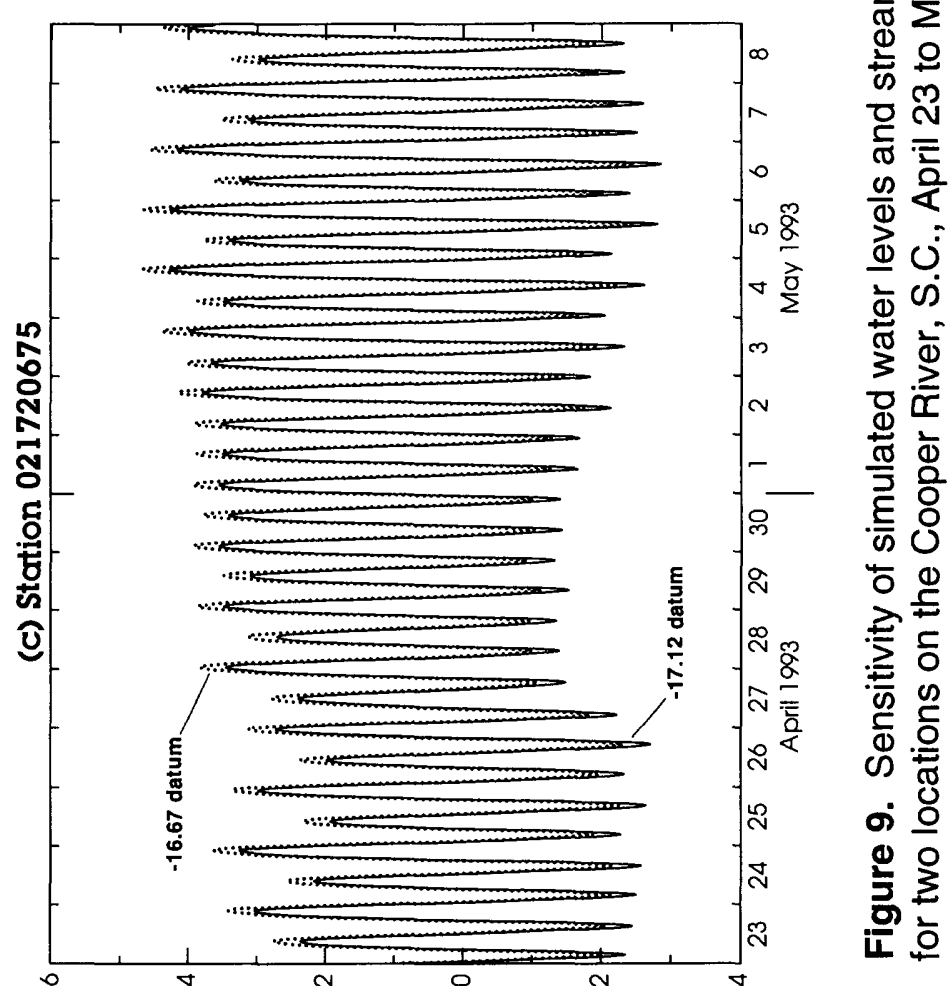

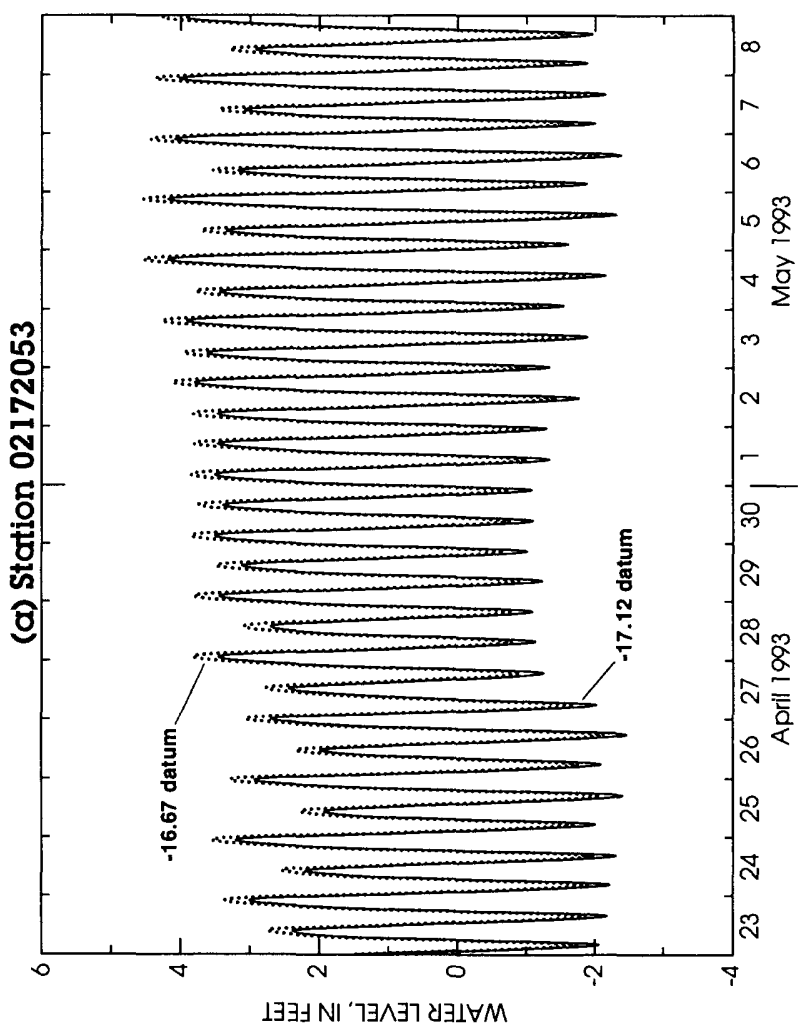

$1 \exists \exists \exists N \mid `\urcorner \exists \wedge \exists 7$ ป 
Comparisons of the simulated and measured water levels at four locations on the Cooper River and two locations on the Wando River (fig. 10; table 4) show that the model overpredicted the water level at all six stations. The mean of the residuals of the water levels varied from 0.02 to $0.51 \mathrm{ft}$ and the standard deviation of the residuals varied between 0.16 and $0.33 \mathrm{ft}$. The timing errors of the simulations were 15 minutes or less for five of the six simulations. At station 02172019 the timing error was 45 minutes.

Comparisons of the simulated streamflows for four sites on the Cooper River (this study) with simulated streamflows from the Cooper River model (Bower and others, 1993) show the effect of the datum adjustment on the downstream boundary (fig. 11; table 5). In three of the four cases, the Cooper-Wando model underpredicted ebb tide and slightly overpredicted the flood tide. In the three cases (stations 02172050, 02172053, and 021720675), the index of the mean residuals indicates that the Cooper-Wando model simulations underpredicted the Cooper model simulation by 8.0 to 10.1 percent and the simulation of the Cooper-Wando model for station 02172019 overpredicted the Cooper model simulated by 7.4 percent.

Simulated streamflows compared favorably with measured streamflows for five sites on the Wando River (fig. 12; table 5). As discussed earlier, it is often difficult to get satisfactory agreement between measured and simulated hydrographs of tidal sloughs, like the Wando River, when the streamflows vary by two or more orders of magnitude between the upstream and downstream boundaries. During model calibration, emphasis was placed on producing accurate simulations of the large volume of water exchanged on every tidal cycle through the middle and lower reaches of the Wando River. At the upper boundaries (stations 021720694 and 021720695), there was not favorable agreement between the shapes of the simulated and measured streamflow hydrographs as seen in the large index of the standard deviation of the residuals (59.9 and 66.9 percent, respectively), but there was favorable agreement between the magnitude of the simulated and measured streamflows as seen by the low index of the mean of the residuals (-5.0 and -0.9 percent, respectively). The large error in the index of standard deviation was acceptable because of the low streamflows. The calibration simulations at stations 0217206947 and 0217206955 underpredicted the measured streamflow by 9.4 and 4.8 percent, respectively. The calibration simulation at station 021720698 overpredicted the streamflow by 2.2 percent. The index of the standard deviation of the residuals at the three sites varied from 14.5 to 15.6 percent.

The calibration of the mass-transport model was accomplished by the datum adjustment of $0.45 \mathrm{ft}$ to the hydraulic model as previously discussed and by adjustments to the dispersion factor. A dispersion factor of 0.15 was used for the entire model except for particular reaches of the Cooper River and the upper reaches of the Wando River and Guerin Creek. In the reaches of the Cooper River, in the vicinity of the freshwater and saltwater interface, a dispersion factor of 0.75 was used to account for the greater dispersion due to the mixing of the freshwater and saltwater. In the upper reaches of the Wando River (above the confluence of the Wando River and Guerin Creek), where there is little freshwater inflow, a dispersion factor of 0.10 was used. The simulated and calculated salinity values compare favorably at the four sites on the Cooper and Wando Rivers (fig. 13; table 6). On the Cooper River, near the upper extent of saltwater interface at station 02172053 , salt remained in the system although the simulated salinity concentrations underpredicted the maximum salinity concentration (fig. 13a). The large indices of the mean of 

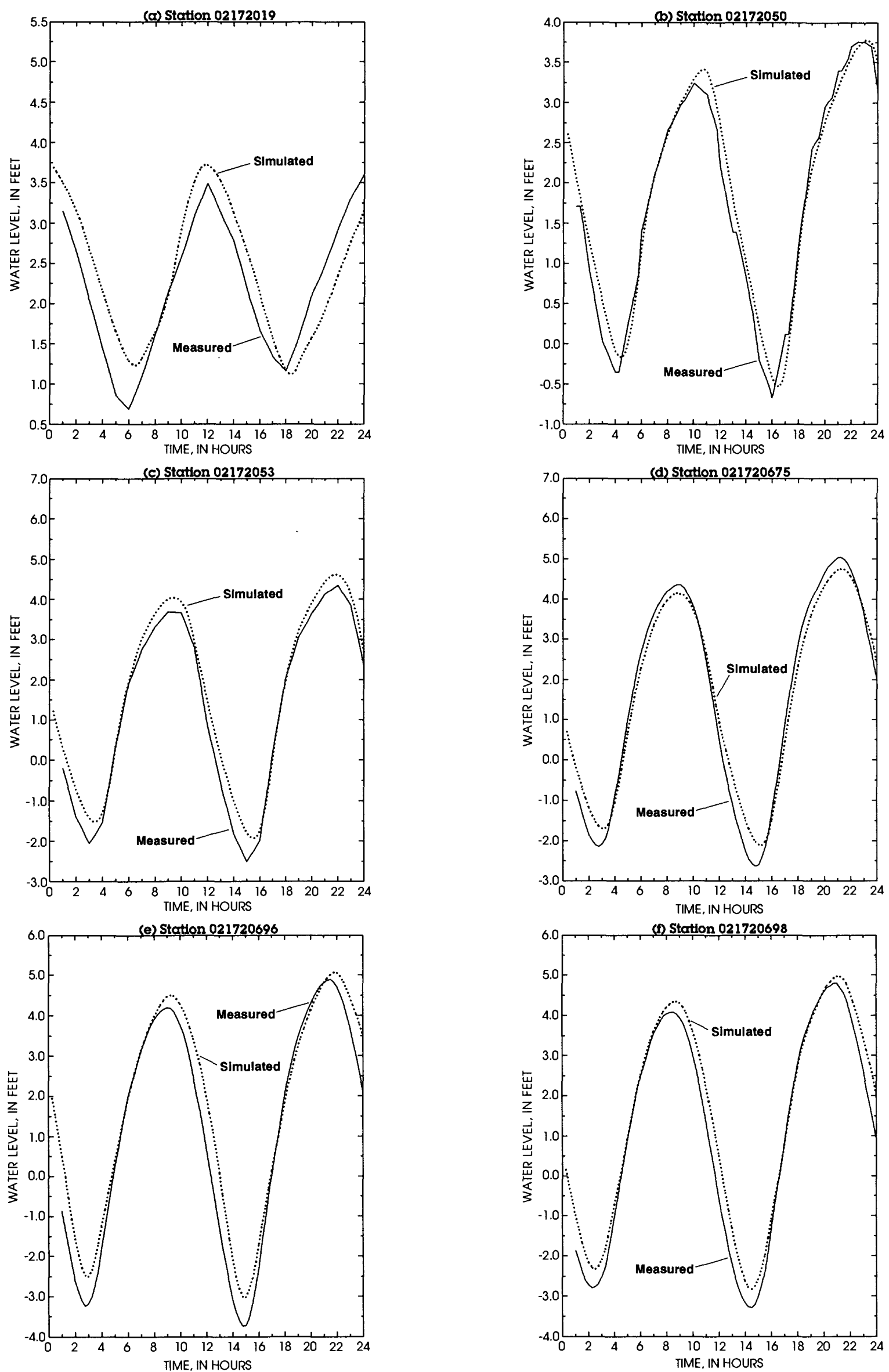

Figure 10. Simulated and measured water levels used in the hydraulic model calibration for four locations on the Cooper River and two locations on the Wando River, S.C., July 30, 1992. 
Table 4. Summary of water-level calibration simulations for four locations on the Cooper River and two locations on the Wando River, S.C.

[min, minutes; $\mathrm{ft}$, feet]

\begin{tabular}{|c|c|c|c|c|}
\hline $\begin{array}{l}\text { Station } \\
\text { number } \\
\text { (fig. 3) }\end{array}$ & Date & $\begin{array}{l}\text { Timing } \\
\text { error } \\
\text { (min) }\end{array}$ & $\begin{array}{l}\text { Mean of } \\
\text { residuals } \\
\text { (ft) }\end{array}$ & $\begin{array}{c}\text { Standard deviation } \\
\text { of residuals } \\
\text { (ft) }\end{array}$ \\
\hline \multicolumn{5}{|c|}{ Cooper River } \\
\hline 02172019 & $07 / 30 / 92$ & 45 & 0.16 & 0.31 \\
\hline 02172050 & $07 / 30 / 92$ & 15 & .09 & .16 \\
\hline 02172053 & $07 / 30 / 92$ & 0 & .33 & .23 \\
\hline 021720675 & $07 / 30 / 92$ & 15 & .02 & .33 \\
\hline \multicolumn{5}{|c|}{ Wando River } \\
\hline 021720696 & $07 / 30 / 92$ & 15 & .51 & .31 \\
\hline 021720698 & $07 / 30 / 92$ & 15 & .39 & .31 \\
\hline
\end{tabular}

${ }^{1}$ Positive timing error means the simulated hydrograph occurred later than the measured hydrograph.

${ }^{2}$ Residual is computed by subtracting the measured water level from the simulated water level.

the residuals and the standard deviation of the residuals (table 6) was due in part to the low mean concentrations of salinity at the station. Farther downstream on the Cooper River, at station 021720675 , the range of the simulated salinity concentrations compared favorably with the range of the calculated salinity concentrations, although it was out of phase by approximately 2 hours (fig. 13b; table 6).

On the Wando River at station 021720696, salinity data were missing for July 31, 1992. The simulated and calculated salinity concentrations data for July 30, 1992 show good agreement between the simulated and calculated salinity concentrations with indices of the mean of the residuals and standard deviation of the residuals of 0.6 and 1.9 percent, respectively (fig. 13c; table 6). Farther downstream on the Wando River at station 021720698 , continuous salinity data were not available during the measurements. Field measurements made during the tidal cycle on July 30 were available and are plotted with the simulated values (fig. 13d; table 6). The simulated and calculated salinity concentrations compare favorably with indices of the mean of the residuals and standard deviation of the residuals $0 .-3.2$ and 6.2 percent, respectively, although the simulated values are graphically slightly out of phase with the calculated values. 

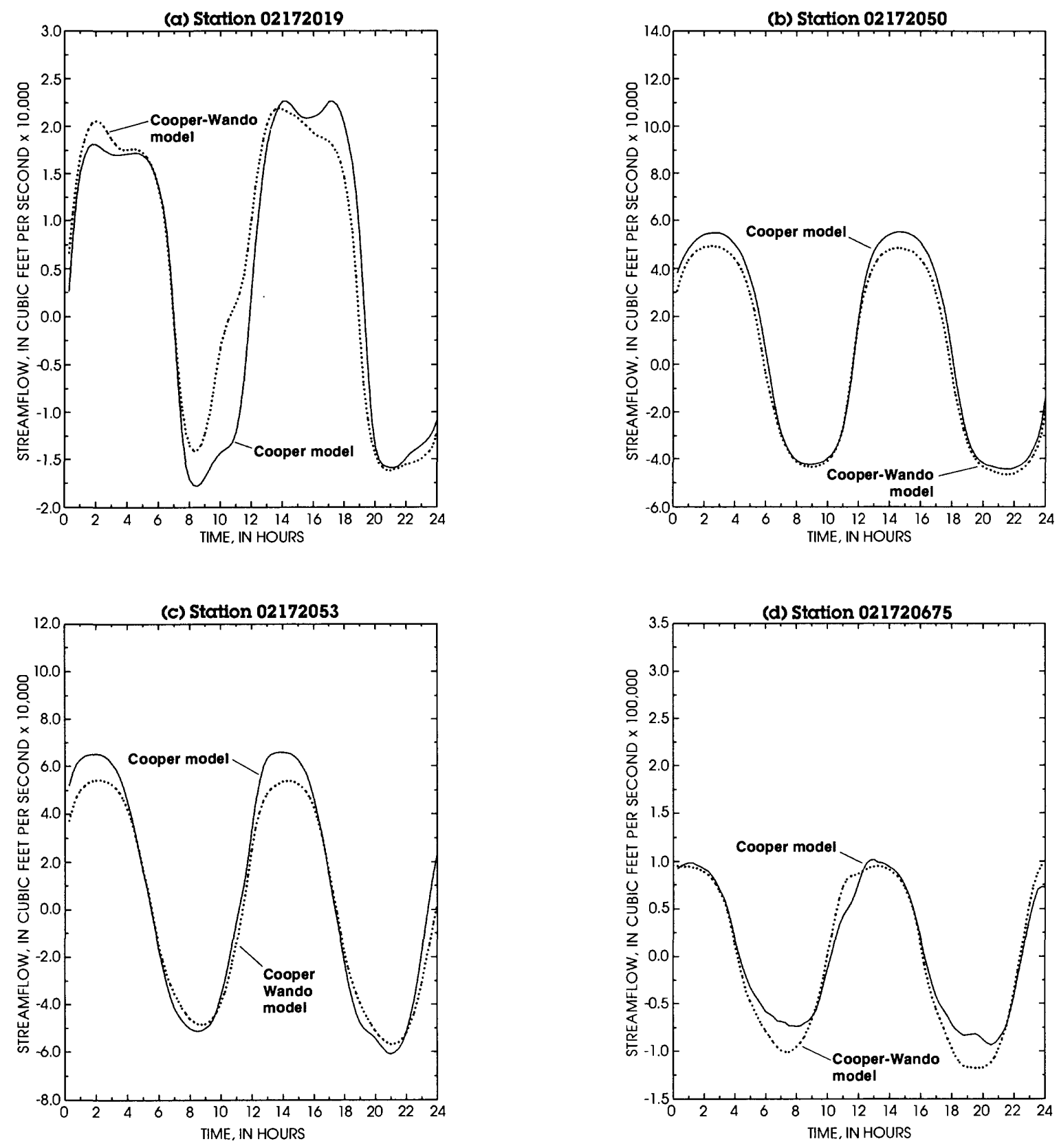

Figure 11. Simulated streamflow from two models used in the hydraulic model calibration for four locations on the Cooper River, S.C., July 30, 1992. 
Table 5. Summary of streamflow calibration simulations for four locations on the Cooper River and five locations on the Wando River, S.C.

[min, minutes; $\mathrm{ft}^{3} / \mathrm{s}$, cubic feet per second]

\begin{tabular}{|c|c|c|c|c|c|}
\hline $\begin{array}{l}\text { Station } \\
\text { number } \\
\text { (fig. 4) }\end{array}$ & Date & $\begin{array}{l}\text { Timing } \\
\text { error } \\
\text { (min) }\end{array}$ & $\begin{array}{c}\text { Index } \\
\text { of the mean } \\
\text { of the residuals }{ }^{2} \\
\text { (percent) }\end{array}$ & $\begin{array}{c}\text { Index } \\
\text { of the mean } \\
\text { of the standard } \\
\text { deviation } \\
\text { of the residuals }{ }^{3} \\
\text { (percent) }\end{array}$ & $\begin{array}{c}\text { Mean absolute } \\
\text { measured } \\
\text { streamflow } \\
\left(\mathrm{ft}^{3} / \mathrm{s}\right)\end{array}$ \\
\hline \multicolumn{6}{|c|}{ Cooper River } \\
\hline 02172019 & $07 / 30 / 92$ & 0 & 7.4 & 25.7 & 15,100 \\
\hline 02172050 & $07 / 30 / 92$ & 0 & -10.1 & 12.0 & 38,100 \\
\hline 02172053 & $07 / 30 / 92$ & 15 & -8.0 & 20.0 & 42,100 \\
\hline 021720675 & $07 / 30 / 92$ & 0 & -9.5 & 23.1 & $\quad 63,100$ \\
\hline \multicolumn{6}{|c|}{ Wando } \\
\hline 021720694 & $07 / 30 / 92$ & 30 & -5.0 & 59.9 & 585 \\
\hline 0217206947 & $07 / 30 / 92$ & 30 & -9.4 & 15.6 & 17,100 \\
\hline 021720695 & 07/30/92 & 15 & -.9 & 66.9 & 353 \\
\hline 0217206955 & 07/30/92 & 0 & -4.8 & 14.5 & 7,760 \\
\hline 021720698 & 07/30/92 & 15 & 2.2 & 14.5 & 105,000 \\
\hline
\end{tabular}

${ }^{1}$ Positive timing error means the simulated hydrograph occurred later than the measured hydrograph.

${ }^{2}$ Percentage of the mean of the residual is computed by dividing the mean of the streamflow residual by the mean absolute measured streamflow.

${ }^{3}$ Percentage of the standard deviation of the residuals is computed by dividing the standard deviation of the streamflow residuals by the mean absolute measured streamflow.

The models were validated using measured and calculated data different from those used for calibration. The parameters used to calibrate the hydraulic and mass-transport models were not changed in the validation process. Streamflows were measured on the Wando River on September 24, 1992. Water-level data for that date were unavailable for station 021720675 , which is the downstream boundary for the Cooper River model (Bower and others, 1993). Comparison streamflow hydrographs of the Cooper-Wando model with the Cooper model were generated using data for September 13, 1992. 

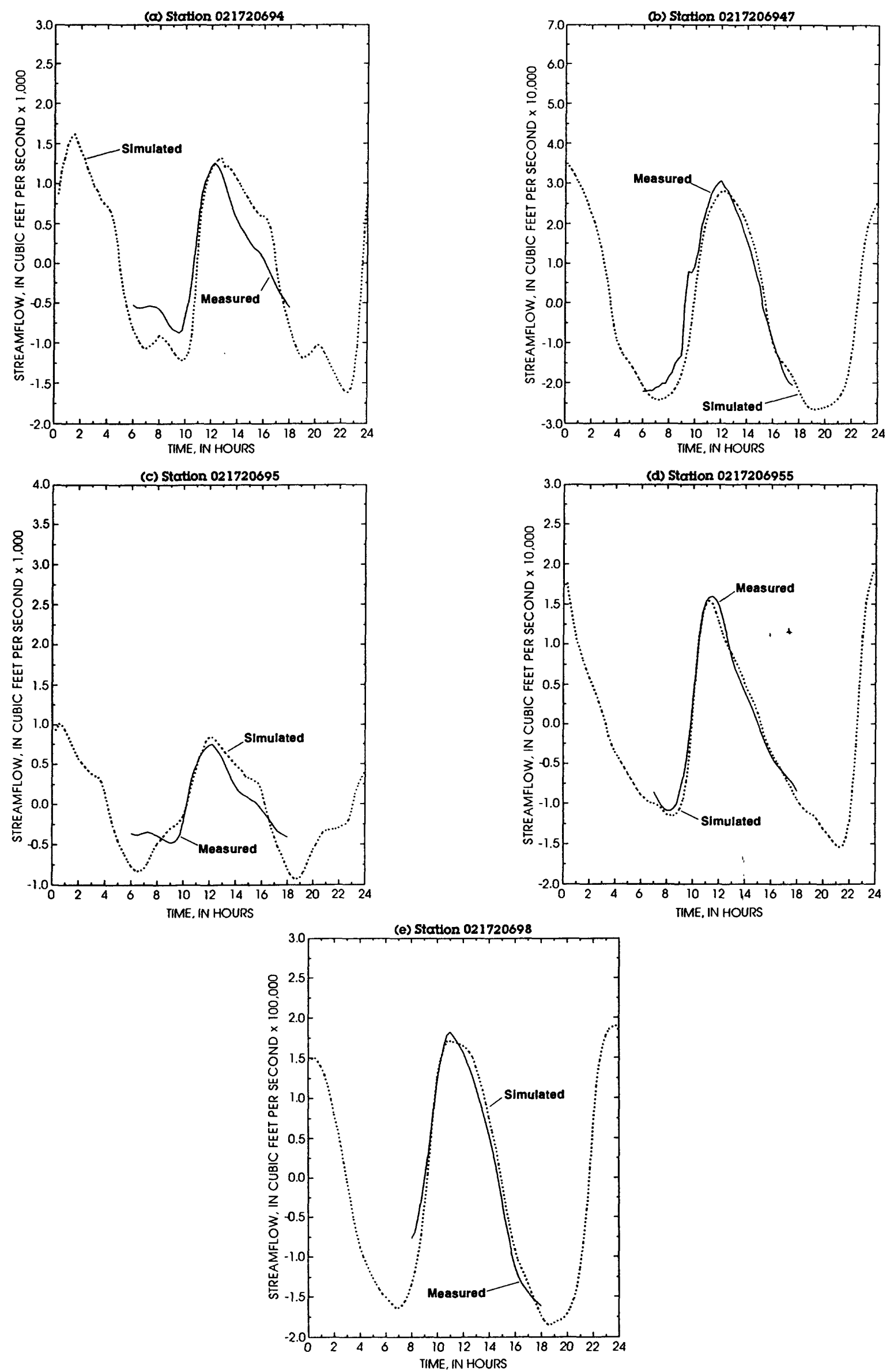

Figure 12. Simulated and measured streamflow used in the hydraulic model calibration for five locations on the Wando River, S.C., July 30, 1992. 

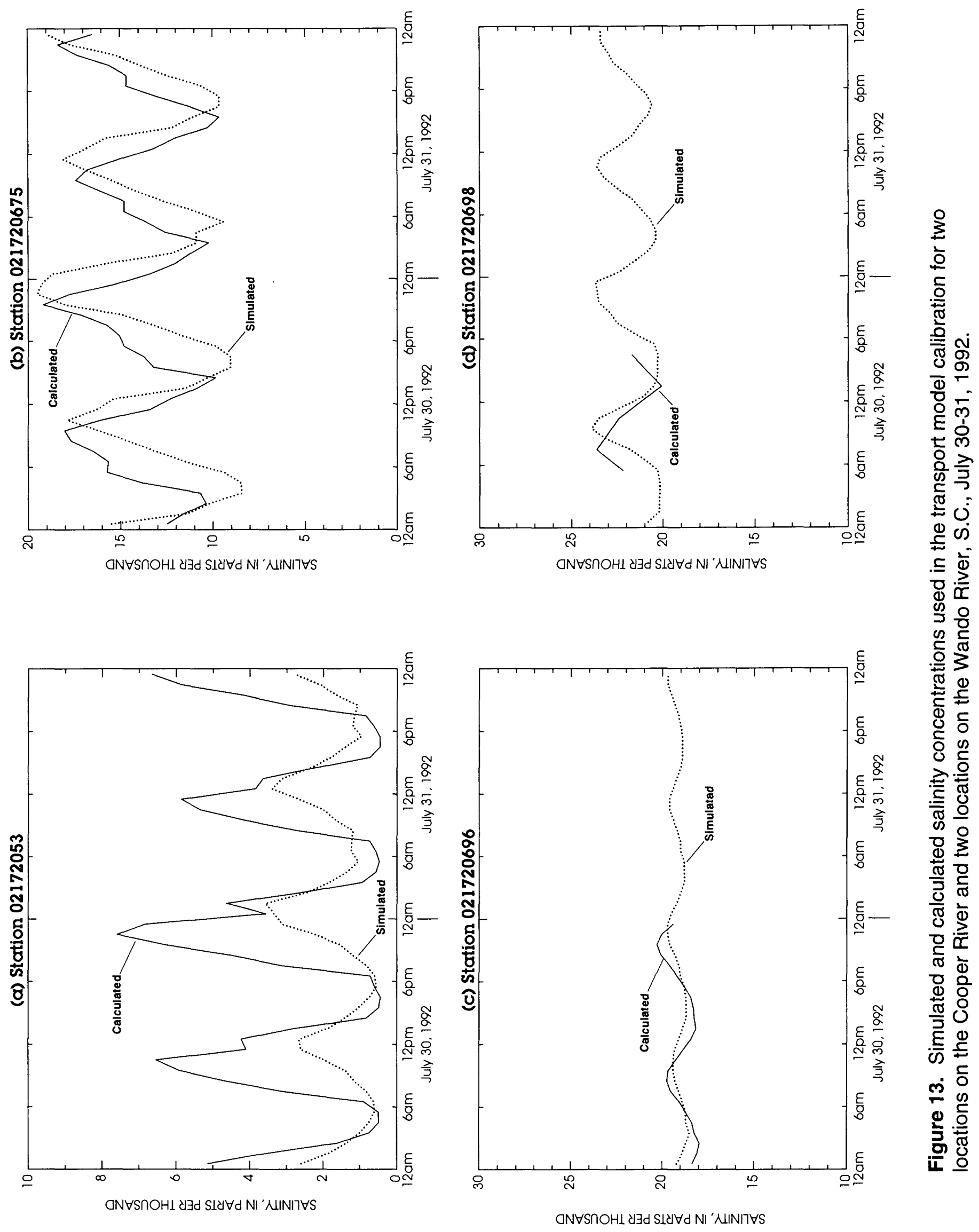
Table 6. Summary of salinity calibration simulations for two locations on the Cooper River and two locations on the Wando River, S.C.

[min, minutes; --, not enough data to compute timing error; ppt, parts per thousand]

\begin{tabular}{|c|c|c|c|c|c|}
\hline $\begin{array}{c}\text { Station } \\
\text { number } \\
\text { (fig. 3) }\end{array}$ & Date & $\begin{array}{l}\text { Timing } \\
\text { error } \\
\text { (min) }\end{array}$ & $\begin{array}{c}\text { Index } \\
\text { of the mean } \\
\text { of the residuals }{ }^{2} \\
\text { (percent) }\end{array}$ & $\begin{array}{c}\text { Index } \\
\text { of the mean } \\
\text { of the standard } \\
\text { deviation } \\
\text { of the residuals }{ }^{3} \\
\text { (percent) }\end{array}$ & $\begin{array}{l}\text { Mean } \\
\text { calculated } \\
\text { salinity } \\
\text { (ppt) }\end{array}$ \\
\hline \multicolumn{6}{|c|}{ Cooper River } \\
\hline 02172053 & $07 / 30-31 / 92$ & 120 & -38.9 & 52.6 & 2.9 \\
\hline 021720675 & $07 / 30-31 / 92$ & 120 & -4.4 & 9.4 & 14.3 \\
\hline \multicolumn{6}{|c|}{ Wando } \\
\hline 021720696 & $07 / 30 / 92$ & 60 & .6 & 1.9 & 19.0 \\
\hline 021720698 & $07 / 30 / 92$ & -- & -3.2 & 6.2 & 22.0 \\
\hline
\end{tabular}

\footnotetext{
${ }^{1}$ Positive timing error means the simulated hydrograph occurred later than the calculated hydrograph.

2 Percentage of the mean of the residual is computed by dividing the mean of the streamflow residual by the mean calculated salinity.

${ }^{3}$ Percentage of the standard deviation of the residuals is computed by dividing the standard deviation of the streamflow residuals by the mean calculated salinity.
}

The water-level validation hydrographs, like the calibration hydrographs, show the effect of the datum adjustment on the downstream boundary (fig. 14; table 7). The model overpredicted high- and low-slack tide levels at four of the five stations. At station 02172050, the mean of the residuals is $0.01 \mathrm{ft}$. In four of the five locations, the mean and standard deviation of the residuals is less than the $0.45 \mathrm{ft}$ datum adjustment in the model. The simulated water-level hydrograph at station 02172019 underpredicted the water level and is 45 minutes out of phase with the measured hydrograph.

The validation streamflow hydrographs for September 13, 1992, comparing the Cooper model (Bower and others, 1993) with the Cooper-Wando model (this study), show the CooperWando model underpredicting the simulated streamflow at three of the four locations on the Cooper River by approximately 18 percent (fig. 15; table 8). The validation simulation for station 02172019 overpredicted the Cooper model by 6.2 percent. 

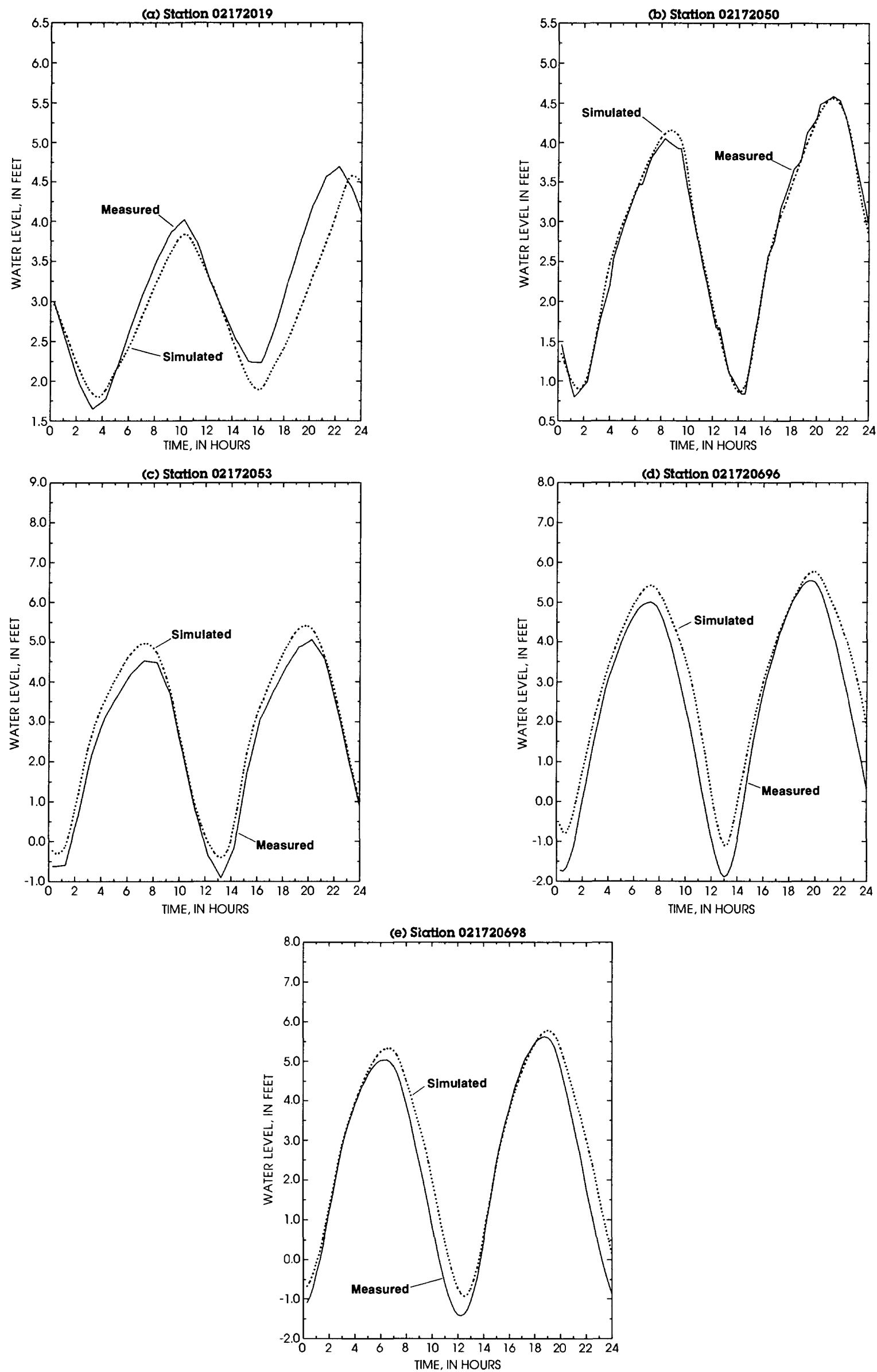

Figure 14. Simulated and measured water levels used in the hydraulic model validation for three locations on the Cooper River and two locations on the Wando River, S.C., September 24, 1992. 
Table 7. Summary of water-level validation simulations for three locations on the Cooper River and two locations on the Wando River, S.C.

[min, minutes; ft, feet]

\begin{tabular}{|c|c|c|c|c|}
\hline $\begin{array}{l}\text { Station } \\
\text { number } \\
\text { (fig. 3) }\end{array}$ & Date & $\begin{array}{c}\text { Timing error } \\
(\min )\end{array}$ & $\begin{array}{l}\text { Mean of } \\
\text { residuals } \\
\text { (ft) }\end{array}$ & $\begin{array}{l}\text { Standard } \\
\text { deviation of } \\
\text { residuals } \\
\text { (ft) }\end{array}$ \\
\hline \multicolumn{5}{|c|}{ Cooper River } \\
\hline 02172019 & $09 / 24 / 92$ & 45 & -0.20 & 0.24 \\
\hline 02172050 & $09 / 24 / 92$ & 0 & .01 & .17 \\
\hline 02172053 & $09 / 24 / 92$ & 0 & .34 & .12 \\
\hline \multicolumn{5}{|c|}{ Wando River } \\
\hline 021720696 & $09 / 24 / 92$ & 30 & .63 & .45 \\
\hline 021720698 & $09 / 24 / 92$ & 30 & .42 & .29 \\
\hline
\end{tabular}

${ }^{1}$ Positive timing error means the simulated hydrograph occurred later than the measured hydrograph.

${ }^{2}$ Residual is computed by subtracting the measured water level from the simulated water level.

The validation streamflow hydrographs for September 24, 1992, compare favorably with the measured streamflow hydrographs for the Wando River (fig. 16; table 8). As with the calibration streamflow measurements on the Wando River, four of the five stations underpredicted the measured streamflow. Simulated streamflows at station 021720698 slightly overpredicted the streamflow with an index of the mean of the residuals of 0.7 percent. The hydrographs at stations 021720698 (fig. 16e) and 0217206947 (fig. 16b) show good predictions of the total volume of water at the two locations. The model overpredicted the peak streamflow at station 0217206955. The magnitude of the simulated and measured streamflows at the two upstream boundaries agreed favorably, although, as with the calibration hydrographs, the shapes of the hydrographs do not agree closely.

The validation simulations of salinity concentration for the September 24-25, 1992, measurements do not agree as favorably as the calibration simulation (fig. 17; table 9). At station 02172053 (fig. 17a) on the Cooper River, salinity is staying in the system but the model overpredicted the peak concentration by 1 to 2 ppt. As seen in the calibration summary statistics, the high values of the indices of the mean of the residuals and the standard deviation of the residuals was due in part to the low mean concentration of salinity at the station. Salinity data for station 021720675 on the Cooper River were missing for the period of the validation measurements. The simulated salinity concentrations for station 021720696 on the Wando River (fig. 17b) were within the range of the calculated values, but the simulation does not have the amplitude of the calculated values. The simulated salinity concentrations at station 021720698 on the Wando River (fig. 17c) overpredicted the measured values by $4 \mathrm{ppt}$, but the simulated concentrations showed the same amplitude as the measured values. 

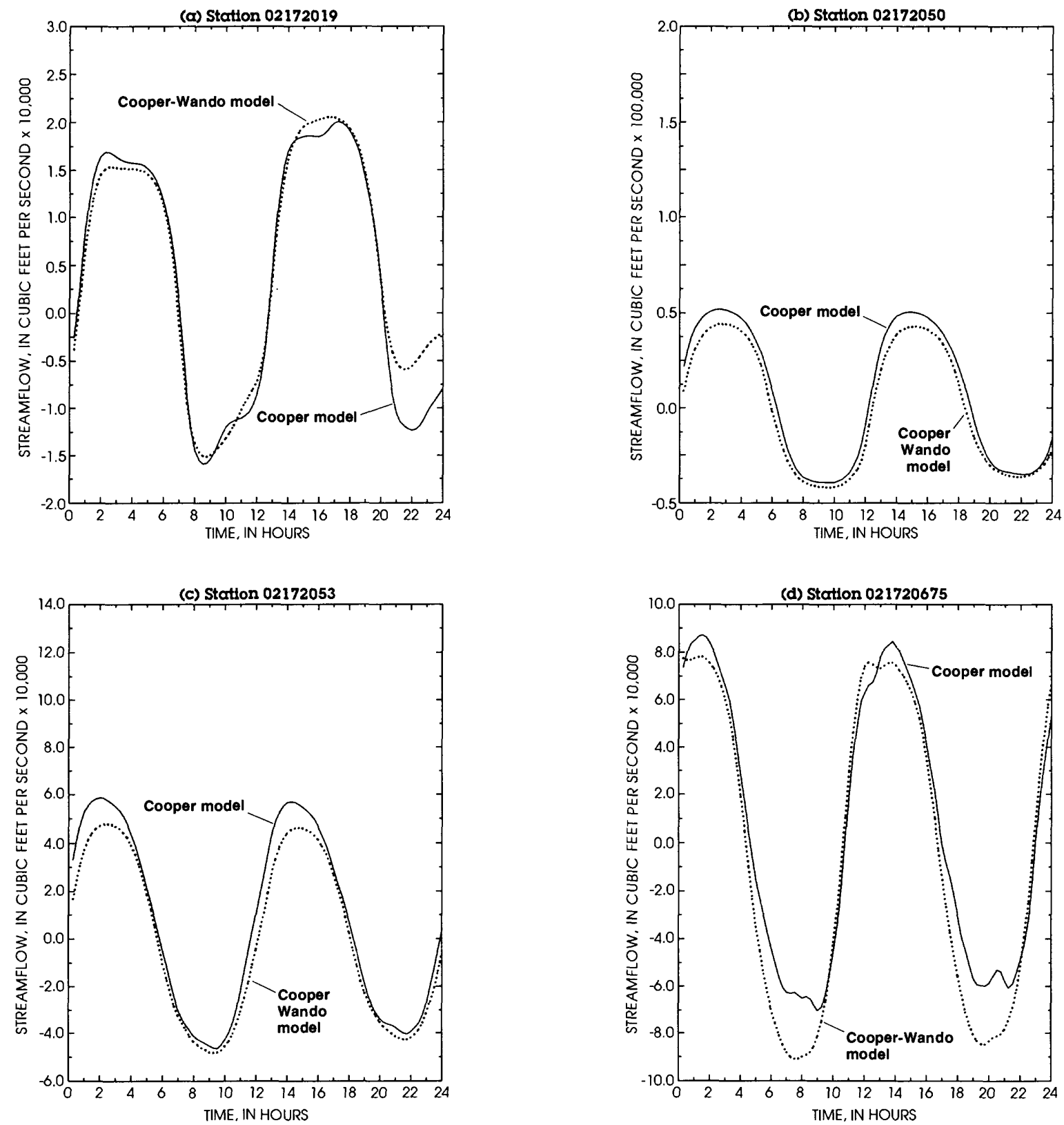

Figure 15. Simulated streamflow from two models used in the hydraulic model validation for four locations on the Cooper River, S.C., September 13, 1992. 
Table 8. Summary of streamflow validation simulations for four locations on the Cooper River and five locations on the Wando River, S.C.

[min, minutes; $\mathrm{ft}^{3} / \mathrm{s}$, cubic feet per second]

\begin{tabular}{|c|c|c|c|c|c|}
\hline $\begin{array}{l}\text { Station } \\
\text { number } \\
\text { (fig. 4) }\end{array}$ & Date & $\begin{array}{l}\text { Timing } \\
\text { error }^{1} \\
\text { (min) }\end{array}$ & $\begin{array}{c}\text { Index } \\
\text { of the mean } \\
\text { of the residuals }{ }^{2} \\
\text { (percent) }\end{array}$ & $\begin{array}{c}\text { Index } \\
\text { of the mean } \\
\text { of the standard } \\
\text { deviation } \\
\text { of the residuals } \\
\text { (percent) }\end{array}$ & $\begin{array}{c}\text { Mean absolute } \\
\text { measured } \\
\text { streamflow } \\
\left(\mathrm{ft}^{3} / \mathrm{s}\right)\end{array}$ \\
\hline \multicolumn{6}{|c|}{ Cooper River } \\
\hline 02172019 & $09 / 13 / 92$ & 15 & 6.2 & 20.2 & 12,600 \\
\hline 02172050 & $09 / 13 / 92$ & 15 & -17.7 & 12.2 & 33,500 \\
\hline 02172053 & $09 / 13 / 92$ & 15 & -18.1 & 16.0 & 34,500 \\
\hline 021720675 & $09 / 13 / 92$ & 0 & -18.4 & 19.0 & 51,400 \\
\hline \multicolumn{6}{|c|}{ Wando River } \\
\hline 021720694 & $09 / 24 / 92$ & 30 & -5.4 & 43.2 & 875 \\
\hline 0217206947 & $09 / 24 / 92$ & 15 & -0.9 & 17.0 & 18,400 \\
\hline 021720695 & $09 / 24 / 92$ & 15 & -7.5 & 49.4 & 548 \\
\hline 0217206955 & $09 / 24 / 92$ & 15 & -0.2 & 17.8 & 10,200 \\
\hline 021720698 & $09 / 24 / 92$ & 15 & 0.7 & 20.0 & 129,000 \\
\hline
\end{tabular}

\footnotetext{
${ }^{1}$ Positive timing error means the simulated hydrograph occurred later than the measured hydrograph.

${ }^{2}$ Percentage of the mean of the residual is computed by dividing the mean of the streamflow residual by the mean absolute measured streamflow.

${ }^{3}$ Percentage of the standard deviation of the residuals is computed by dividing the standard deviation of the streamflow residuals by the mean absolute measured streamflow.
}

Tidal-cycle measurements made on Goose Creek for the calibration and validation of the Goose Creek model (McKellar and others, 1995) were used to check the simulated streamflows on Goose Creek (fig. 18; table 10). The Goose Creek model used station 02172066 as the upstream boundary and station 021720675 (at the mouth of Goose Creek on the Cooper River) as the downstream boundary (fig. 4). As seen in the calibration water-level hydrograph of station 021720675, the Cooper-Wando model slightly overpredicted the water level (mean of residuals of $0.02 \mathrm{ft}$ ) for this reach of the Cooper River (fig. 10d; table 4). For the dates of the streamflow measurements on Goose Creek, the Cooper-Wando model overpredicted the water level at station 021720675. When the Goose Creek model was incorporated into the Cooper-Wando model, adjustments were made to the datum at station 02172066 to compensate for the overprediction of the water levels at station 021720675 (the downstream boundary of the Goose Creek model) and to ensure that there was a net positive streamflow from Goose Creek. The published datum of station 02172066 is $-6.99 \mathrm{ft}$; however, the datum used in the model was $-6.64 \mathrm{ft}$. 

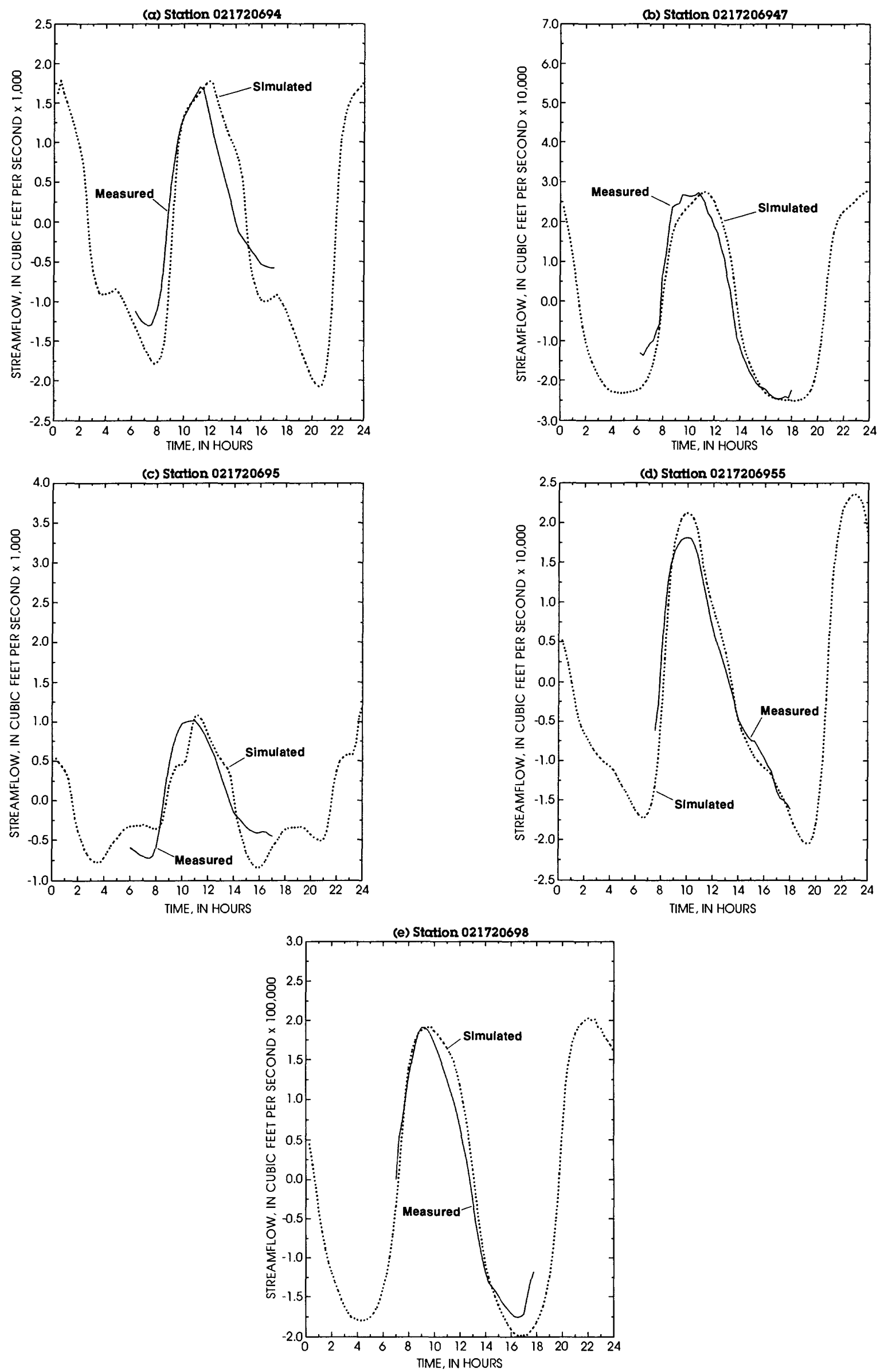

Figure 16. Simulated and measured streamflow used in the hydraulic model validation for five locations on the Wando River, S.C., September 24, 1992. 

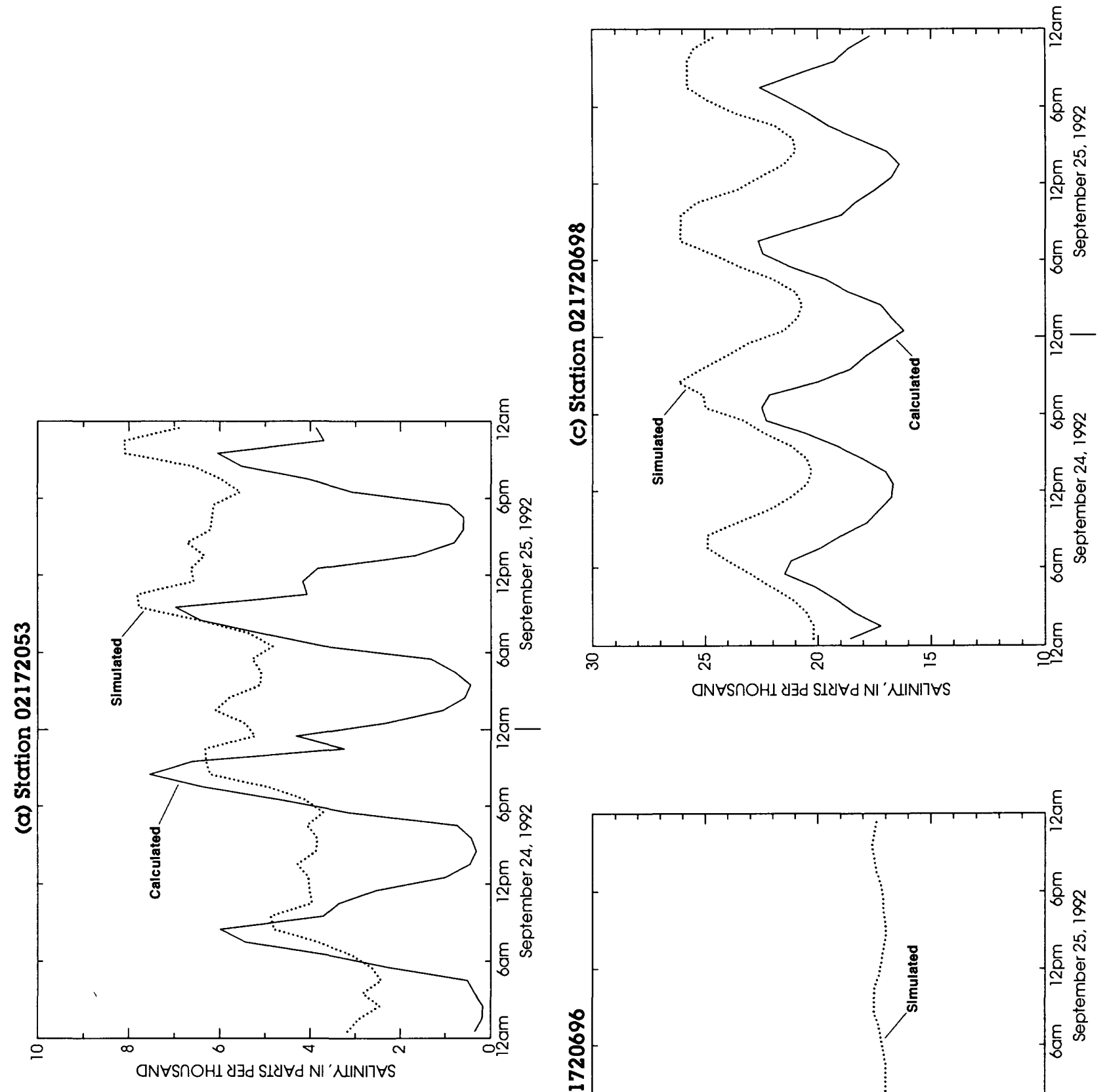

동

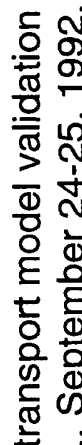

$\stackrel{\$}{\ddagger} \dot{0}$

.

윰

$د$

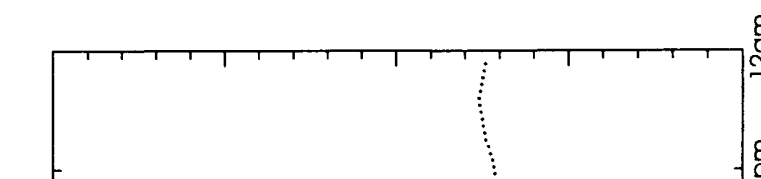

도음

은 인

홍

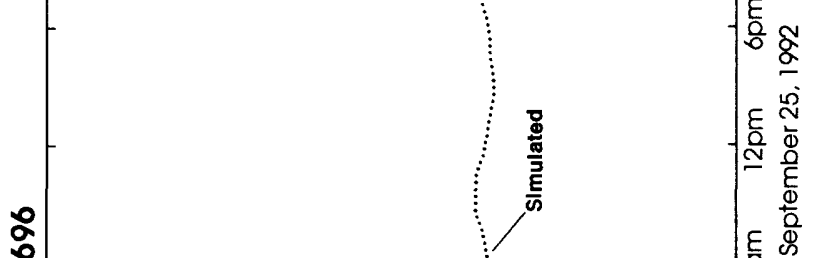

ㄷ

엉

늘응

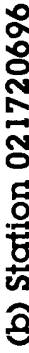


Table 9. Summary of salinity validation simulations for one location on the Cooper River and two locations on the Wando River, S.C.

[min, minutes; --, not enough data to compute timing error; ppt, parts per thousand]

\begin{tabular}{|c|c|c|c|c|c|}
\hline $\begin{array}{c}\text { Station } \\
\text { number } \\
\text { (fig. 3) }\end{array}$ & Date & $\begin{array}{l}\text { Timing } \\
\text { error } \\
\text { (min) }\end{array}$ & $\begin{array}{c}\text { Index of the } \\
\text { mean } \\
\text { of the residuals }{ }^{2} \\
\text { (percent) }\end{array}$ & $\begin{array}{c}\text { Index } \\
\text { of the mean } \\
\text { of the standard } \\
\text { deviation } \\
\text { of the residuals } \\
\text { (percent) }\end{array}$ & $\begin{array}{l}\text { Mean } \\
\text { calculated } \\
\text { salinity } \\
\text { (ppt) }\end{array}$ \\
\hline
\end{tabular}

\begin{tabular}{|c|c|c|c|c|c|}
\hline \multicolumn{6}{|c|}{ Cooper River } \\
\hline 02172053 & $09 / 24-25 / 92$ & 60 & 76.8 & 58.7 & 3.0 \\
\hline \multicolumn{6}{|c|}{ Wando River } \\
\hline 021720696 & $09 / 24-25 / 92$ & -- & 2.5 & 7.8 & 16.7 \\
\hline 021720698 & $09 / 24-25 / 92$ & 120 & 21.3 & 3.8 & 19.2 \\
\hline
\end{tabular}

On October 3, 1992, a tidal-cycle streamflow measurement was made at the mouth of Goose Creek (station 021720674) and on December 4, 1992, tidal-cycle streamflow measurements were made at the upstream boundary (station 02172066) and at the mouth. The simulated-streamflow hydrograph of October 3,1992, shows a satisfactory prediction of the magnitude of the measured streamflow with indices of the mean of the residuals and standard deviation of the residuals of -0.4 and 15.6 percent, respectively, although the simulation is out-of-phase by 60 minutes (fig. 18a; table 10). The simulated streamflow hydrographs for December 4, 1992, show similar results (fig. 18c). The timing error was reduced by 45 minutes to 15 minutes and the indices of the mean of the residuals and standard deviation of the residuals were slightly higher at -7.5 and 33.6 percent, respectively. The simulated hydrograph at the upstream boundary (station 02172066) approximates the magnitude of the flood tide, but differs from the shape of the measured-streamflow hydrograph (fig. 18b). As with the simulations at the upper branch of the Wando River (station 021720694) and Guerin Creek (station 021720695), the large error in the indices was considered acceptable because of the low streamflows. 

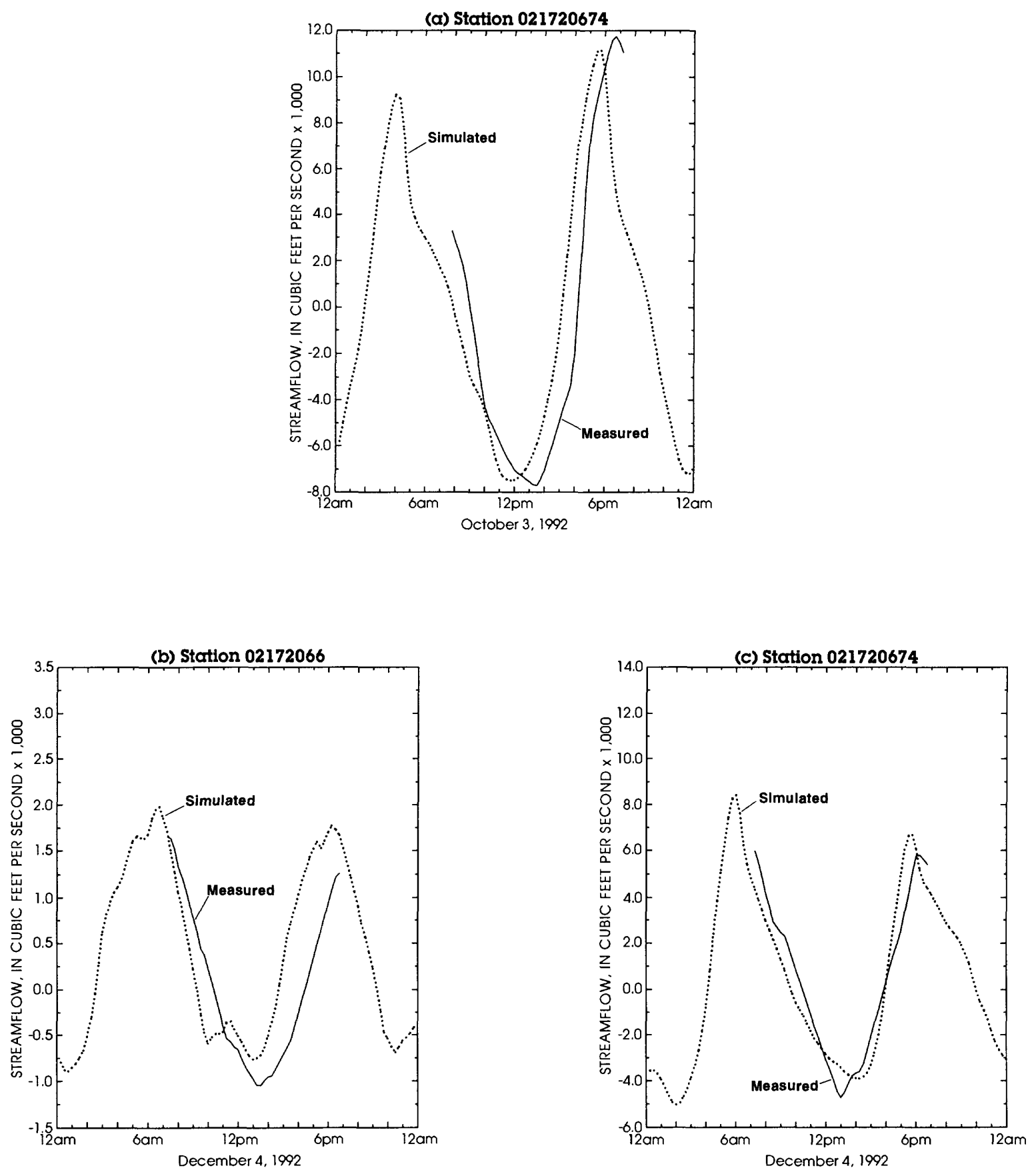

Figure 18. Simulated and measured streamflow for two locations on Goose Creek, S.C., October 3 and December 4, 1992. 
Table 10. Summary of streamflow simulations for two locations on Goose Creek, S.C.

[min, minutes; $\mathrm{ft}^{3} / \mathrm{s}$, cubic feet per second]

\begin{tabular}{|c|c|c|c|c|c|}
\hline $\begin{array}{l}\text { Station } \\
\text { number } \\
\text { (fig. 4) }\end{array}$ & Date & $\begin{array}{l}\text { Timing } \\
\text { error } 1 \\
\text { (min) }\end{array}$ & $\begin{array}{c}\text { Index } \\
\text { of the mean } \\
\text { of the residuals }{ }^{2} \\
\text { (percent) }\end{array}$ & $\begin{array}{c}\text { Index } \\
\text { of the mean } \\
\text { of the standard } \\
\text { deviation } \\
\text { of the residuals } \\
\text { (percent) }\end{array}$ & $\begin{array}{c}\text { Mean } \\
\text { measured } \\
\text { streamflow } \\
\left(\mathrm{ft}^{3} / \mathbf{s}\right)\end{array}$ \\
\hline 021720674 & $10 / 03 / 92$ & -60 & -0.4 & 15.6 & 5,860 \\
\hline 02172066 & $12 / 04 / 92$ & -75 & 44.5 & 28.0 & 741 \\
\hline 021720674 & $12 / 04 / 92$ & -15 & -7.5 & 33.6 & 2,970 \\
\hline
\end{tabular}

${ }^{1}$ Negative sign means the simulated hydrograph occurred earlier than the measured hydrograph.

${ }^{2}$ Percentage of the mean of the residual is computed by dividing the mean of the streamflow residual by the mean absolute measured streamflow.

${ }^{3}$ Percentage of the standard deviation of the residuals is computed by dividing the standard deviation of the stream flow residuals by the mean absolute measured streamflow.

\section{Sensitivity Analysis}

The sensitivity of the simulated water level, streamflow, and salinity concentrations to changes in downstream gage datum, channel geometry, and roughness coefficient in the BRANCH model and the sensitivity of the simulated salinity concentration to changes in dispersion factors in the BLTM were analyzed. The models were used to simulate water level, streamflow, and salinity transport in an area of major water-quality concern (station 021720675) on the Cooper River for a 3-day period (July 28-30, 1992). The results of the sensitivity analysis are representative for the reach of the model in the vicinity of station 021720675 and may not be characteristic of other reaches of the model with different hydraulic characteristics.

The water-level simulations were most sensitive to changes in the downstream datum (fig. 19a). Lowering the downstream gage datum by 0.5 feet $(-16.67$ to $-17.17 \mathrm{ft})$ decreased the high-slack tide on July 29,1992 from 5.67 to $4.66 \mathrm{ft}$ and decreased the low-slack from -1.75 to $-2.79 \mathrm{ft}$. Water levels were least sensitive to changes in channel geometry (fig. 19c). A 50-percent increase in the cross-sectional area (or channel geometry) had no effect on the highslack tide of July 29,1992 , and decreased the low-slack tide from -1.75 to $-1.73 \mathrm{ft}$. A 50-percent decrease in the cross-sectional areas increased the high-slack tide by $0.02 \mathrm{ft}$ (from 5.67 to $5.69 \mathrm{ft}$ ) and decreased the low-slack tide by $0.01 \mathrm{ft}$ (from -1.75 to $-1.76 \mathrm{ft}$ ).

Whereas the water-level simulations were insensitive to changes in the channel geometry, streamflow simulations were sensitive to these changes (fig. 19d). A 50-percent increase in the cross-sectional area (equivalent to a 50 -percent increase in the volume of the model), increased 

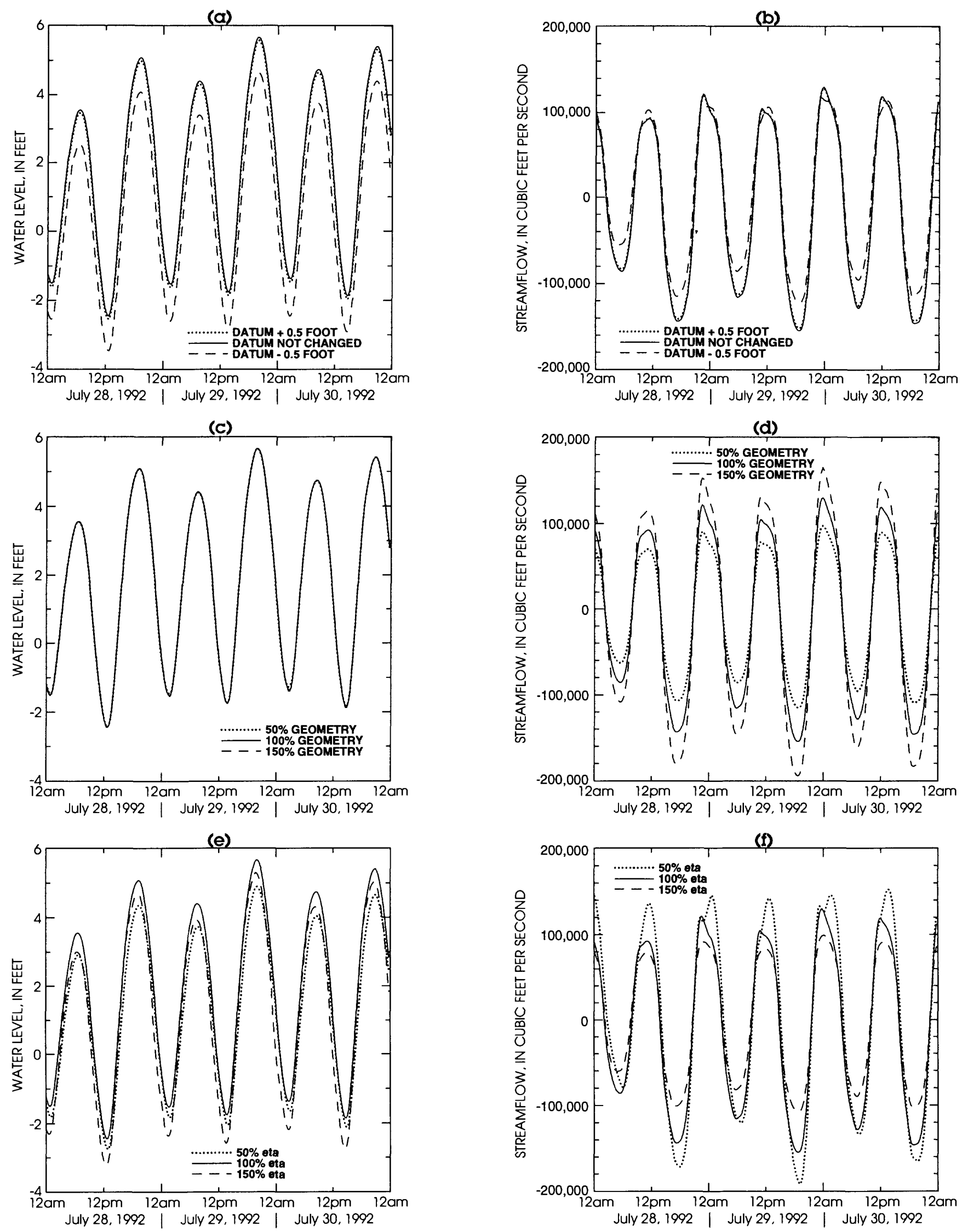

Figure 19. Sensitivity of water levels and streamflow to changes in gage datum ( $a$ and $b$ ), channel geometry ( $c$ and d), and roughness coefficient (e and $f$ ) for the Cooper River at Army Depot near North Charleston, S.C., July 28-30, 1992. 
the peak flood and ebb tidal streamflow of July 29,1992 , from $-155,000$ to $-195,000 \mathrm{ft}^{3} / \mathrm{s}$ and 130,000 to $165,000 \mathrm{ft}^{3} / \mathrm{s}$, respectively. A 50 -percent decrease in the cross-sectional area decreased the peak flood and ebb streamflow $-155,000$ to $-115,000 \mathrm{ft}^{3} / \mathrm{s}$ and 130,000 to $97,500 \mathrm{ft}^{3} / \mathrm{s}$, respectively. Streamflows also were very sensitive to changes in the roughness coefficient (eta) (fig. 19f). Increasing eta by 50 percent decreased the peak flood and ebb streamflows of July 29,1992 , from $-155,000$ to $-106,000 \mathrm{ft}^{3} / \mathrm{s}$ and 130,000 to $99,300 \mathrm{ft}^{3} / \mathrm{s}$, respectively. Decreasing eta by 50 percent increased the peak flood- and ebb-tidal streamflow from $-155,000$ to $-191,000 \mathrm{ft}^{3} / \mathrm{s}$ and 130,000 to $133,000 \mathrm{ft}^{3} / \mathrm{s}$, respectively. Raising the downstream gage datum by $0.5 \mathrm{ft}$ (decreasing the slope in the system) had little effect on the streamflow as compared to a $-0.5 \mathrm{ft}$ change in the downstream gage datum (fig. 19b). Lowering the downstream gage datum by $0.5 \mathrm{ft}$ (increasing the slope in the system) decreased the peak flood-tidal streamflow from $-155,000$ to $-122,000 \mathrm{ft}^{3} / \mathrm{s}$ and decreased the peak ebb-tidal streamflow from 130,000 to $117,000 \mathrm{ft}^{3} / \mathrm{s}$.

The simulated salinity concentrations were highly sensitive to changes of $0.5 \mathrm{ft}$ in gage datum at the downstream boundary (fig. 20a). An increase of 0.5 feet in the downstream gage datum $(-16.67$ to $-16.17 \mathrm{ft})$ increased the salinity concentrations and removed the tidal signal from the simulated salinity concentrations. The mean salinity concentration for the 3-day simulation increased 107 percent ( 12.7 to $26.3 \mathrm{ppt}$ ). The range of the salinity concentration went from a tidal oscillation with a standard deviation from 3.9 ppt to a nearly constant concentration with a standard deviation of $0.0 \mathrm{ppt}$. A decrease of $0.5 \mathrm{ft}$ in the downstream gage datum (-16.67 to $-17.17 \mathrm{ft}$ ) decreased the 3-day mean salinity concentration by 47 percent (12.7 to $6.7 \mathrm{ppt}$ ) and the standard deviation decreased from 3.9 to $3.4 \mathrm{ppt}$.

The effects of changes in the channel geometry on the salinity concentrations were calculated. The salinity concentrations increased when the cross-sectional area (channel geometry) was increased or decreased by 50 percent (fig. 20b). A larger increase occurred when the cross-sectional area was increased by 50 percent. The mean salinity concentration for the 3-day simulation increased by 24 percent ( 12.7 to $15.7 \mathrm{ppt}$ ) and the standard deviation decreased from 3.9 to 3.2. The increase in the cross-sectional area increased the flows throughout the system. The increased flows changed the flux of salt from the boundaries and increased the simulated salinity concentrations. A 50-percent decrease in the channel geometry increased the 3-day mean salinity concentration by 11 percent $(12.7$ to $14.1 \mathrm{ppt})$ and decreased the standard deviation from 3.9 to $3.5 \mathrm{ppt}$. An increase in the salinity concentrations with a decrease in the cross-sectional area is probably because of a decrease in the dilution of salinity concentration due to decreased upstream freshwater streamflows.

The effects of a 50-percent change in the roughness coefficient (eta) on salinity concentrations were calculated. A 50-percent decrease in eta increased the flows through the system, increased the 3 -day mean salinity concentration by 13 percent (12.7 to $14.3 \mathrm{ppt}$ ), and increased the standard deviation from 3.9 to $4.3 \mathrm{ppt}$ (fig. 20c). A 50-percent increase in eta decreased the flows in the system, increased the 3-day mean salinity concentration by 5.5 percent (12.7 to $13.4 \mathrm{ppt}$ ), and decreased the standard deviation from 3.9 to $2.9 \mathrm{ppt}$.

The effects of a 50-percent change in the dispersion factor on salinity concentrations were also calculated. An increase in the dispersion factor of 50 percent increased the 3-day mean salinity concentration by 21 percent ( 12.7 to $15.4 \mathrm{ppt}$ ) and decreased the standard deviation from 3.9 to $3.4 \mathrm{ppt}$ (fig. 20d). A 50-percent decrease in the dispersion factor decreased the 3-day mean salinity concentration by 24 percent ( 12.7 to $9.6 \mathrm{ppt}$ ) and increased the standard deviation from 3.9 to $4.3 \mathrm{ppt}$. 

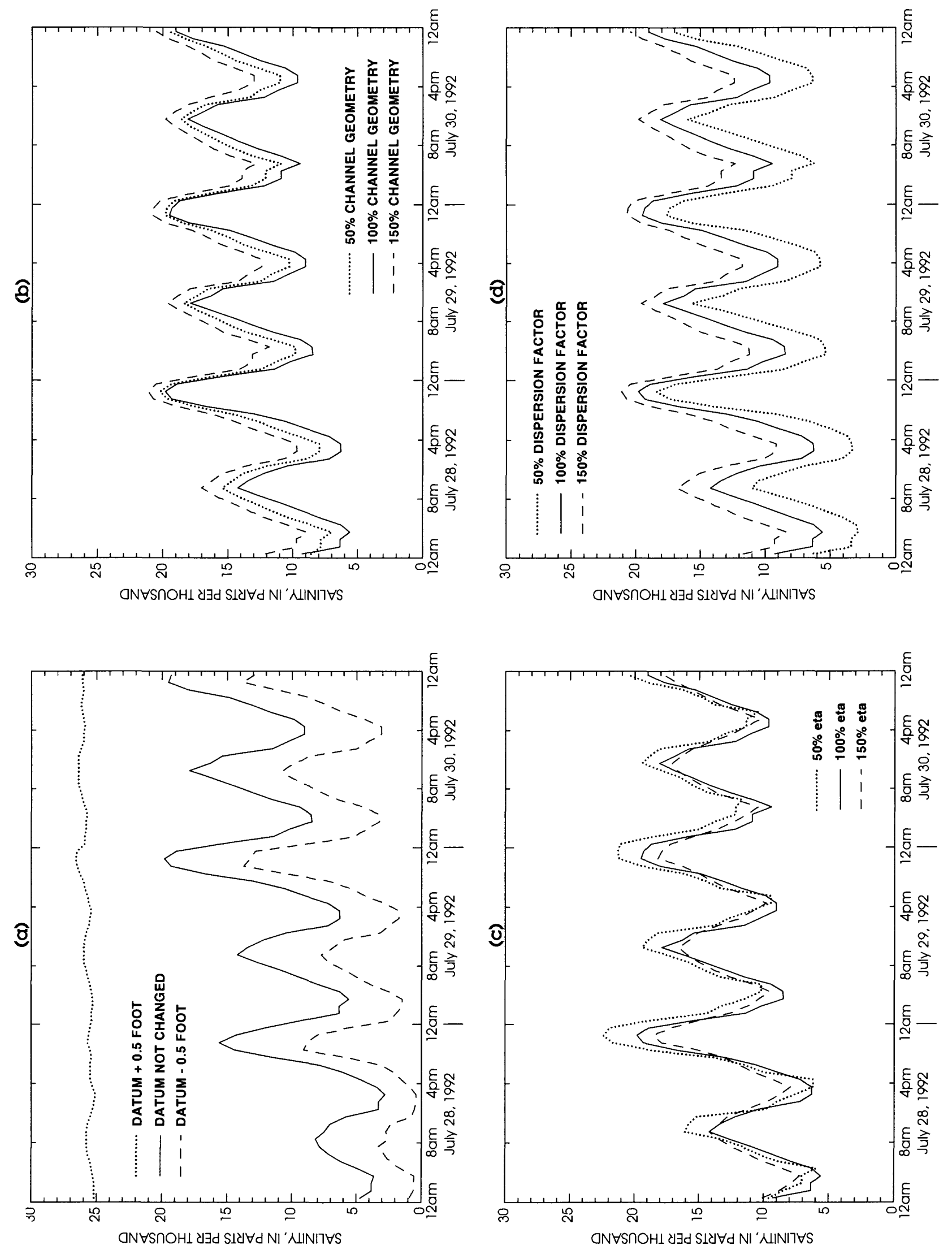

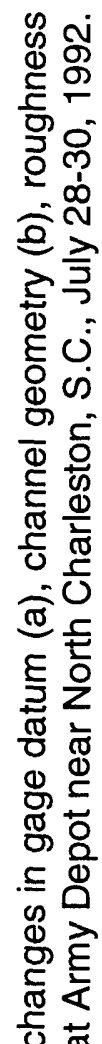

을

롣

음

등

잉

흥

동 으

흥

\&

元

है ธ

के क

¿

$\geq .9$

응

ฮ

ஸे

จิ ั้

는 은

온 


\section{SUMMARY}

The U.S. Geological Survey's one-dimensional, unsteady-flow model BRANCH and the Branched Lagrangian Transport Model (BLTM) were calibrated and validated for the Cooper and Wando Rivers and their tributaries in the Charleston Harbor area of South Carolina. The study area included the Cooper River from the Pinopolis Dam to the Customs House, the Wando River from Ward Bridge to the confluence with the Cooper River, Durham Canal, East Branch Cooper River, Flag Creek, Yellow House Creek, Goose Creek, and Guerin Creek. The hydraulic and mass-transport models were calibrated and validated using field measurements of water level, streamflow, and calculated salinity concentrations. Data used in calibrating and validating the hydraulic and mass transport models included: water levels from four locations on the Cooper River and two locations on the Wando River, tidal-cycle streamflow measurements from five locations on the Wando River, simulated tidal-cycle streamflows from a validated model of the Cooper River at four locations, and calculated salinity concentrations at two locations on the Cooper River and two locations on the Wando River.

The preliminary model simulations of the mass transport of the Cooper and Wando Rivers were not satisfactory. Although the simulated water-level and streamflow hydrographs compared favorably with the measured hydrographs, the simulated salinity concentrations were much lower than the measured concentrations. The BLTM model was sensitive to changes to the gage datum of the downstream water-level boundary used in the BRANCH model. Satisfactory calibration of the mass-transport model was achieved by applying a 0.45 - $\mathrm{ft}$ datum adjustment to the downstream water-level boundary data.

Summary statistics were generated to quantify the error in the calibration and validation simulations. Summary statistics for water-level simulations included timing error, mean of the residuals, and the standard deviation of the residuals. Of the 11 water-level simulations used in the calibration and validation of the model, seven had timing errors of 15 minutes or less, two had timing errors of 30 minutes, and two had timing errors of 45 minutes. The mean of the residuals varied from -0.20 to $0.63 \mathrm{ft}$ and the standard deviation of the residuals varied from 0.12 to $0.45 \mathrm{ft}$.

Summary statistics for the streamflow simulations included timing error, an index of the mean of the residuals (given as a percentage), and an index of the standard deviation of the residuals (also given as an percentage). The indices are not a true percentage because it will not be representative throughout the range of streamflows of the simulations (especially when those values are low or pass through zero). Of the 18 simulations used in the calibration and validation, 15 simulations had timing errors or 15 minutes or less and three simulations had timing errors of 30 minutes. For the 18 simulations the index of the mean of the residuals varied from -18.4 to 7.4 percent. For the four simulations made at the upstream boundaries of the Wando River and Guerin Creek (where the streamflows are two orders of magnitude less than the mainstem), the indices of the standard deviation of the mean of the residuals were high (43.2 to 66.9 percent). For the other 14 simulations, the indices of the standard deviation of the residuals varied from 12.0 to 25.7 percent.

Summary statistics for the salinity simulations included timing error, index of the mean of the residuals, and an index of the standard deviation of the residuals. Of the seven calibration and validation simulations, two had timing errors of 60 minutes, three had timing errors of 120 minutes and two did not have enough data to compute the timing error. Five of the simulations 
had indices of the mean of the residuals and the standard deviation of the residuals that varied from -4.4 to 21.3 percent and 1.9 to 9.4 percent, respectively. In the two simulations where the mean salinity concentration were low (3.0 ppt or less) the summary statistics were high. The indices of the mean of the residuals and standard deviation of the residuals varied from -38.9 to 76.8 percent and 52.6 to 58.7 percent, respectively.

The sensitivity of the simulated water level, streamflow, and salinity concentrations to changes in downstream gage datum, channel geometry, and roughness coefficient in the BRANCH model and the sensitivity of the simulated salinity to changes in dispersion factors in the BLTM were analyzed. Water-level simulations were most sensitive to changes in the downstream datum. A decrease in the downstream gage datum by $0.5 \mathrm{ft}$ decreased the high- and low-slack tide on July 29,1992 , by 0.99 and $1.04 \mathrm{ft}$, respectively.

The simulated streamflows were most sensitive to changes in channel geometry and roughness coefficient. A 50-percent increase in the channel geometry increased the maximum flood and ebb tide on July 29,1992 , by 40,000 and $35,000 \mathrm{ft}^{3} / \mathrm{s}$, respectively. A 50 -percent increase in the roughness coefficient decreased the maximum flood and ebb tide by 49,000 and $30,700 \mathrm{ft}^{3} / \mathrm{s}$, respectively.

The salinity simulations were most sensitive to changes in the downstream datum. A decrease in the downstream gage datum of 0.5 feet increased the simulated 3-day (July 28-30, 1992) mean salinity concentration by 107 percent ( 12.7 to $26.3 \mathrm{ppt}$ ). The range of the salinity concentration went from a tidal oscillation with a standard deviation from $3.9 \mathrm{ppt}$ to a nearly constant salinity concentration with a standard deviation of $0.0 \mathrm{ppt}$. An increase in the downstream gage datum decreased the simulated 3-day mean salinity concentration by 47 percent (12.7 to $6.7 \mathrm{ppt}$ ) and decreased the standard deviation from 3.9 to $3.4 \mathrm{ppt}$. 


\section{SELECTED REFERENCES}

Ambrose, R.B., Wool, T. A., Connolly, G.A., and Schanz, R.A., 1988, WASP4, a hydrodynamic and water quality model, model theory, user's manual, and programmer's guide: U.S. Environmental Protection Agency, Athens, Georgia, EPA/600/3-87/03, 200 p.

Bennett, C.S., Cooney, T.W., Jones, K.H, and Drewes, P.A., 1994, Water resources data, South Carolina, water year 1993, U.S. Geological Survey Water-Data Report SC-93-1, 494 p.

Bower, D.E., Sanders, C.L., Jr., and Conrads, P.A., 1993, Retention time simulation for Bushy Park Reservoir near Charleston, South Carolina: U.S. Geological Survey Water-Resources Investigation Report 93-4070, $47 \mathrm{p}$.

Chestnut, David, 1989, A review of Charleston Harbor water-quality data 1974-1987: South Carolina Department of Health and Environmental Control Technical Report No. 002-89, $124 \mathrm{p}$.

Cooney, T.W., Jones, K.H, Drewes, P.A., Gissendanner, J.W., and Church, B.W., 1995, Water resources data, South Carolina, water year 1994: U.S. Geological Survey Water-Data Report SC-94-1, $520 \mathrm{p}$.

Cooney, T.W., Jones, K.H., Drewes, P.A., Gissendanner, J.W., and Church, B.W., 1996, Water resources data, South Carolina, water year 1995: U.S. Geological Survey Water-Data Report SC-95-1, $634 \mathrm{p}$.

Drewes, P.A., and Conrads, P.A., 1995, Assimilative capacity of the Waccamaw River and the Atlantic Intracoastal Waterway near Myrtle Beach, South Carolina, 1989-92: U.S. Geological Survey Water-Resources Investigations Report 95-4111, 58 p.

Jobson, H.E., 1980, Comment on a new collocation method for the solution of the convectiondominated transport equation, by Pinder, George E., and Sharpiro, Allen, 1979, (in Water Resources Research, v. 15, no. 5, p. 1177-1182) Water Resources Research, v. 16, no. 6, p. 1135-1136.

-----1981, Temperature and the solute-transport simulation in streamflow using a Lagrangian reference frame: U.S. Geological Survey Water-Resources Investigations Report 87-4163, $165 \mathrm{p}$.

Jobson, H.E., and Schoelhamer, D.H., 1987, Users manual for a Branched Lagrangian Transport Model: U.S. Geological Survey Water-Resources Investigation Report 87-4163, $73 \mathrm{p}$.

Kjerfve, Björn, 1976, The Santee-Cooper: A study of estuarine manipulations, in M.L. Wiley, ed., Estuarine Processes, v. 1, Academic Press, New York, p. 44-56.

Kjerfve, Björn, and Magill, K.E., 1990, Salinity changes in Charleston Harbor 1922-1987: Journal of Waterway, Port, Coastal, and Ocean Engineering 166:153-168.

McKellar, H.N., Douglas, Annette; Smith, Adrian; Munnerlyn, Thadeus; and Rao, R.P., 1995, Nutrient dynamics and water-quality interactions in the Goose Creek sub-basin of the Charleston Harbor estuary. Final report to the South Carolina Department of Health and Environmental Control, Charleston Harbor Project, and the South Carolina Sea Grant Consortium [variously paged]. 


\section{SELECTED REFERENCES--Continued}

Miller, R. L., Bradford, W.L., and Peters, N.E., 1988, Specific conductance--theoretical considerations and application to analytical quality control: U.S. Geological Survey WaterSupply Paper 2311, 16 p.

National Oceanic and Atmospheric Administration, 1992, Charleston Harbor--Chart 11524, 39th edition: U.S. Department of Commerce, National Ocean Service.

-----1995, Tide Tables 1995, High and Low Predictions - East Coast of North and South America, Including Greenland: U.S. Department of Commerce, National Ocean Service, 301 p.

Patterson, G.G., 1983, Effect of the proposed Cooper River Rediversion on sedimentation in Charleston Harbor, South Carolina: U.S. Geological Survey Water-Resources Investigations Report 83-4198, 65 p.

Schaffranek, R.W., Baltzer, R.A., and Goldberg, D.E., 1981, A model for simulation of flow in singular and interconnected channels: U.S. Geological Survey Techniques of WaterResources Investigation, book 7, chap. C3, 100 p.

Smith, G.D., 1985, Numerical solution of partial differential equations, finite difference methods, Third Edition: Brunel University, p. 43-45.

South Carolina Department of Health and Environmental Control, 1991, Water Quality Modeling of the Cooper River: S.C. Department of Health and Environment Control Technical Report 005-91, 30 p.

-----1993, Water Classifications and Standards (Reg. 61-68) and Classified Waters (Reg.61-69) for the State of South Carolina, $36 \mathrm{p}$.

-----1996, Watershed water quality Management Strategy--Catawba-Santee Basin: Technical Report No. 002-96, 266 p.

South Carolina Water Resources Commission, 1979, Cooper River controlled low-flow study: S.C. Water Resources Commission, Report No. 131, 352 p.

Teeter, A.M., 1989, Effects of Cooper River rediversion flows on shoaling conditions at Charleston Harbor, Charleston, South Carolina: U.S. Army Corps of Engineers Technical Report HL-89-3, 113 p.

Teeter, A.M., and Pankov, Walter, 1989, Schematic numerical modeling of harbor deepening effects on sedimentation Charleston, South Carolina: U.S. Army Corps of Engineers Technical Report HL-89-7, $90 \mathrm{p}$.

Thompson, D.B., 1992, Numerical methods 101-convergence of numerical models, in Jennings, M., and Bhowmik, N.G., eds., Hydraulic engineering: saving a threatened resource--in search of solutions: New York, American Society of Civil Engineers, p. 398-403.

Thomson, N.R., Sykes, J.F., and Lennox, W.C., 1984, A lagrangian porous media mass transport model: Water Resources Research, v. 20, no. 3, p. 391-403.

U.S. Army Corps of Engineers, 1966, Survey report on Cooper River, S.C.: Appendix A, Supplement 1, Field and laboratory studies, methods and results: Charleston District, S.C., $39 \mathrm{p}$. 


\section{SELECTED REFERENCES--Continued}

Van Dolah, R.F., Wendt, P. H., and Wenner, E.L., eds., 1990, Physical and ecological characterization of the Charleston Harbor estuarine system, Final Report: South Carolina Coastal Council, Charleston, South Carolina, 634 p.

Van Dolah, R.F., and Davis, K.B., 1990, Description of Study Area, in Physical and ecological characterization of the Charleston Harbor estuarine system, Final Report: South Carolina Coastal Council, Charleston, South Carolina, p. 7.

Weiss, L.A., Schaffranek, R.W., and deVries, M.P., 1994, Flow and chloride transport in the tidal Hudson River, N.Y.: Proceedings 1994 National Hydraulic Engineer Conference, American Society of Civil Engineers, New York, N.Y., p. 1300-1305. 